\title{
Performance Pay and Applicant Screening
}

\author{
Uwe Jirjahn \\ University of Trier and IZA \\ Jens Mohrenweiser \\ Bournemouth University
}

\begin{abstract}
Using German establishment data, we show that the relationship between intensity of individual-based performance pay and intensity of applicant screening depends on the nature of production. In establishments with increased multitasking, performance pay is positively associated with applicant screening. By contrast, in establishments without increased multitasking, performance pay is negatively associated with applicant screening. We do not find a similar pattern of results for group-based performance pay or profit sharing. Our findings fit the hypothesis that individual-based performance pay induces a positive self-sorting of employees if jobs are less multifaceted. In this case, employers with a high intensity of performance pay do not need intensive applicant screening to ensure a high quality of matches between workers and jobs. However, if jobs are more multifaceted, individual-based performance pay can entail problems of adverse self-sorting. In order to mitigate or overcome these problems, employers making intensive use of performance pay also screen applicants more intensively.
\end{abstract}

Keywords: Performance pay, multitasking, self-sorting, applicant screening, non-managerial employees, managerial employees.

JEL: J33, J60, M51, M52.

Acknowledgements: We thank participants at the 2015 Colloquium of Personnel Economics in Vienna, the IAB/ZEW Workshop "Assessing the Impact of HRM Practices" in Mannheim, and the 2015 British Academy of Management in Portsmouth for valuable comments. Financial support by the German Research Foundation (DFG) through priority program SPP 1764 is gratefully acknowledged.

Address for Correspondence: Uwe Jirjahn, Universität Trier, Fachbereich IV, Lehrstuhl für Arbeitsmarktökonomik, Universitätsring 15, 54286 Trier, Germany, Email: jirjahn@ uni-trier.de. 


\section{Introduction}

Personnel economics has made great progress in analyzing the incentives created within firms. Much less attention has been paid to the hiring strategies of firms (Oyer and Schaefer 2011). This is surprising given that improving the quality of matches between workers and jobs can substantially raise productivity (Autor and Scarborough 2008, Bartling et al. 2012). Usually, a careful selection of employees is viewed as a fundamental part of human resource management in order to improve the quality of matches (Huang and Capelli 2010, Ichniowski et al. 1997). However, the quality of matches not only depends on applicant screening. A firm's personnel policy in general and the use of performance pay in particular may also have an influence on the quality of matches by inducing a self-sorting of applicants.

Our study contributes to the literature by examining the relationship between individualbased performance pay and applicant screening. Lazear (1986, 2000) has shown that performance pay can induce a self-sorting of high-ability employees. ${ }^{1}$ Against this background one may expect that performance pay and applicant screening are substitutes. Employers using performance pay can attract high-ability employees without extensive screening of applicants. Only those employers who do not make intensive use of performance pay may need extensive applicant screening to ensure a sufficiently high ability of their employees.

This prediction presupposes a comprehensive measurement of performance so that performance pay adequately rewards every worker characteristic that is relevant for production. In this case, performance pay can attract workers whose skills and abilities match the various job requirements. However, if the measurement of worker performance is only available for a limited set of dimensions, performance pay may induce a distorted sorting process, as it does not reward all the worker attributes needed for production. Whether or not a comprehensive 
measurement of performance is available depends on the nature of production. As a consequence, potential distortions in the self-sorting process induced by performance pay should depend on the nature of production.

Against this background, we hypothesize that the nature of production plays a moderating role in the relationship between performance pay and applicant screening. A substitutive relationship should hold if production is characterized by a lower degree of multitasking. A low degree of multitasking implies that worker performance can be more easily and comprehensively measured. In this case, performance pay rewards the worker characteristics needed for production and, hence, attracts the right workers reducing the necessity of an intensive applicant screening. By contrast, a complementary relationship should hold if production entails a higher degree of multitasking. A high degree of multitasking implies that performance pay can entail problems of adverse self-sorting. If performance measures are not available for all relevant tasks, performance pay may attract employees who are only strong in the measured performance dimensions, but are weak in the non-measured dimensions. In order to mitigate the problem of adverse self-sorting, the employer has to screen applicants more intensively.

Our empirical analysis uses unique data from German establishments. The data provide information on the intensity of individual performance pay and the intensity of applicant screening for both managerial and non-managerial employees. We use the establishment's focus on high quality, innovativeness or customer-specific solutions as an indication of a production that requires increased multitasking. Our estimates confirm that the nature of production indeed plays a moderating role in the relationship between performance pay and applicant screening. The average share of individual performance pay in employees' earnings and the time taken for the screening of applicants are negatively associated if production is characterized by less 
multitasking. They are positively associated if production is characterized by increased multitasking. Thus, the findings suggest a substitutive relationship between intensity of performance pay and intensity of applicant screening in a less multifaceted work setting and a complementary relationship in a more multifaceted work setting. This holds for managerial and for non-managerial employees.

We also account for the use of performance appraisal systems to examine if the relationship between performance pay and applicant screening depends on how performance is measured. The key pattern of results holds for both establishments using and establishments not using performance appraisals. However, the pattern of results is unique to individual performance pay. We do not find a similar pattern for group-based performance pay or profit sharing.

Our study is related to recent research on performance pay and multidimensional sorting (Bandiera et al. 2015, Cornelissen et al. 2011, Curme and Stefanec 2007, Dohmen and Falk 2011, Heywood et al. 2017). This research has used employee data to show that the self-sorting into performance pay jobs can take place along multiple dimensions of the employees' personal characteristics. Our study indicates that the self-sorting process induced by performance pay is even more complex. Ability itself can be multi-dimensional and the self-sorting process is moderated by the nature of production.

\section{Background Discussion}

The classical sorting model by Lazear (1986) lends itself as a starting point for our discussion. Lazear models performance pay as a self-sorting process by workers who differ in their ability level. He divides the economy into a time rate sector and a performance pay sector. Employers in the time rate sector cannot observe individual worker performance. Thus, the wage of an 
individual worker does not depend on his or her ability. Each worker receives the same time rate. By contrast, employers in the performance pay sector are able to monitor individual worker performance so that they can reward workers according to individual performance. This implies that workers with a higher ability receive a higher performance-related payment. However, performance pay is coupled with a lower base payment to recoup the costs of monitoring. Workers prefer the performance pay sector only if the performance-related pay they can earn dominates the disadvantage of the lower base payment. This condition is met by workers with sufficiently high ability. Hence, high-ability workers sort themselves into performance-pay firms while low-ability workers choose jobs in time-rate firms. The model has received empirical support in Lazear's (2000) case study of the Safelite Glass Corporation. The auto glass company moved 3,000 workers from hourly wages to piece rates resulting in a 44 percent increase in output per worker. Half of the productivity gain came from more able workers being attracted into the piece rate scheme. ${ }^{2}$

While Lazear does not explicitly analyze employers' investments in the selection of new employees, the idea of performance pay as a self-sorting device suggests that performance pay and applicant screening may be substitutes. Employers using performance pay can attract highability workers even without being proactive in screening job applicants for their ability. By contrast, those employers in the time rate sector who are interested in recruiting high-ability workers must rely on screening methods such as evaluations of résumés, references and background checks, applicant testing, and extensive job interviews for selecting appropriate applicants. They offer high fixed wages to attract the applicants being successful in the screening process.

Using a limited-liability principal-agent approach with both moral hazard and adverse 
selection, we develop a model that takes applicant screening explicitly into account. Specifically, we consider high-powered performance pay, low-powered performance pay, and time rates coupled with applicant screening. ${ }^{3}$ In the basic version of the model, we assume a onedimensional task and imagine workers who have either a low or a high ability in the task. ${ }^{4} \mathrm{An}$ employer offering a time rate sets the fixed wage equal to the reservation utility of high-ability workers to ensure that these workers are willing to work for the firm. However, if low-ability workers have a smaller reservation utility than high-ability workers, they have an incentive also to apply for the job. One way to discourage low-ability workers from applying for the job is to couple the time rate with applicant screening. Performance pay stands as an alternative to avoid an adverse selection problem. On the one hand, it prevents low-ability workers from applying for the job, as their ability does not enable them to earn a sufficiently high performance-related wage. On the other hand, it attracts high-ability workers, as it rewards their ability. While lowpowered performance pay and high-powered performance pay both induce a positive self-sorting of high-ability workers, only high-powered performance pay provides an additional incentive to exert high effort.

Altogether, the basic version of our model predicts a substitutive relationship between performance pay and applicant screening. However, to attract workers whose skills and abilities match the various job requirements, performance pay must adequately reward every worker characteristic that is relevant for production. Thus, the prediction of a substitutive relationship between performance pay and applicant screening should rather hold for less multifaceted tasks that allow a comprehensive measurement of worker performance. In an extension of our model, we show that the relationship between performance pay and applicant screening may be different if production is characterized by multitasking. 
Multitasking can be associated with dimensions of worker performance for which individual performance measures are not available. The literature on multitasking usually focuses on the implications for the effort of workers. The inability to reward every type of productive worker activity can cause workers to cut back on productive behaviors for which they are not rewarded (Baker 2002, Holmstrom and Milgrom 1991). For example, piece rates induce workers to exert effort increasing quantity while they provide no incentives to engage in activities such as helping colleagues, maintaining equipment, cultivating customer goodwill, and reducing chances of workplace injury (Artz and Heywood 2015, Bender et al. 2012, Drago and Garvey 1998, Drago and Heywood 1995, Freeman and Kleiner 2005).

An emphasis on performance as measured by one or a few narrow performance indicators may not only distort the allocation of effort across tasks but may also entail problems of adverse self-sorting. ${ }^{5}$ Performance pay may attract workers who have high abilities in the measured performance dimensions and have low abilities in the non-measured performance dimensions. Thus, taking up our example again, piece rates may induce a self-sorting of workers who are strong in producing a high quantity of output but weak in maintaining equipment or cooperating with colleagues. Those workers increase their individual output at the expense of equipment maintenance and helping on the job. In order to avoid such adverse self-sorting, employers using performance pay may invest in applicant screening. While performance pay causes a self-sorting of high-ability workers along the measured performance dimensions, applicant screening ensures sufficiently high abilities in the non-measured performance dimensions. Hence, in case of increased multitasking, combining performance pay with a more careful and in-depth applicant screening can help the employer find the right employees.

In the extension of our model, we consider the case that ability and performance are two- 
dimensional. Only the first dimension of performance can be measured so that performance pay only rewards that dimension. We show that, under multitasking conditions, high-powered performance pay now entails a specific adverse selection problem. Because of the limited liability constraint, the employer must leave a rent to the workers when inducing them to exert effort in the first performance dimension. In other words, workers who have a high ability in the first performance dimension receive a utility greater than their reservation utility when they are on high-powered performance pay. ${ }^{6}$ This implies that they have an incentive to apply for a job with high-powered performance pay even if their ability in the second performance dimension is low. Thus, while high-powered performance pay does not involve an adverse selection problem in the first performance dimension, it entails such problem in the second one. In order to avoid an adverse selection, the employer has to screen applicants with respect to the second dimension of ability. By contrast, low-powered performance pay and applicant screening on the first performance dimension do not involve a rent to workers and, hence, do not entail an adverse selection problem with respect the second dimension. Thus, screening on the second dimension is not required when the employer uses low-powered performance pay or couples a time rate with applicant screening on the first performance dimension.

All in all, the relationship between performance pay and applicant screening should depend on the nature of production. If production is characterized by a lower degree of multitasking, we anticipate a substitutive relationship. Employers using performance pay can induce a self-sorting of high-ability workers and, hence, do not need to rely on extensive applicant screening. ${ }^{7}$ By contrast, if production is characterized by a higher degree of multitasking, there may be a complementary relationship. Employers with an intensive use of performance pay engage in extensive applicant screening in order to avoid an adverse self- 
sorting of workers who have low abilities in the non-measured performance dimensions.

From a practical viewpoint, one may raise the question as to what measures employers can take to screen applicants for multitask jobs. The use of personality tests may be one way to intensify applicant screening. A series of psychological studies show that general personality traits such as the Big Five can predict various dimensions of job performance closely related to multitasking. These dimensions include team-related behavior, service orientation, creative problem solving, innovativeness, and dealing with uncertain work situations (Hough and Oswald 2008, Judge et al. 2008, Penney et al. 2011 and Rothstein and Goffin 2006). Personality traits are even related to counter-productive work behavior such as unsafe behavior or performing tasks incorrectly. Moreover, personality test may identify specific personality characteristics directly linked to multitasking. Polychronicity (the preference to multitask) has been shown as an important indicator of multitasking performance (Conte and Gintoft 2005, Koenig et al. 2010).

We note that examining our predictions empirically requires variation across firms in the intensity of performance pay. As discussed in Appendix A, such variation exists if firms differ in the cost of monitoring individual worker output. Moreover, variation in performance pay intensity may result from imperfect information on its potential advantages and disadvantages (Caroli and van Reenen 2001). Imperfect information on the advantages and disadvantages of performance pay implies that managers are subject to some optimization errors leading to experimentation.

\section{A Model of Performance Pay and Applicant Screening}

We develop an illustrative model to analyze the relationship between performance pay and screening. While Lazear's (1986) analysis focuses on an economy-wide self-sorting equilibrium under the assumption of a zero-profit condition, we consider a single profit-maximizing principal 
choosing the optimal hiring strategy. Our analysis is based on a limited-liability principal-agent model with both moral hazard and adverse selection (Laffont and Martimort 2002).

\subsection{The Basic Model}

A principal wants to hire one agent for a project. The pool of agents consists of two types. Let $\theta \in\{\underline{\theta}, \bar{\theta}\}$ denote an agent's type where a low-ability agent is characterized by $\underline{\theta}$ and a highability agent by $\bar{\theta}$. While agents know of which type they are, the principal cannot immediately observe an agent's type. However, the principal can invest in applicant screening. We assume that screening is perfect and unambiguously reveals the true type of an applicant. The fixed screening cost is given by $z>0$. The reservation utilities of low-ability and high-ability agents are $\underline{U}$ and $\bar{U}$ with $\bar{U}>\underline{U}>0$. This reflects that high-ability agents have better outside options than low-ability agents. The project can either succeed or fail. An agent's output is

$$
Q=\left\{\begin{array}{l}
q>0 \text { with probability } \rho(e, \theta), \\
0 \text { with probability } 1-\rho(e, \theta),
\end{array}\right.
$$

where the success probability $\rho$ is a function of the agent's type $\theta$ and the agent's additional effort $e$. Effort is dichotomous with $e \in\{0,1\}$. We assume that

$$
\begin{aligned}
& \rho(0, \underline{\theta})=0<\rho(1, \underline{\theta})<1, \\
& 0<\rho(0, \bar{\theta})<\rho(1, \bar{\theta})<1, \\
& \rho(1, \underline{\theta})-\rho(0, \underline{\theta})<\rho(1, \bar{\theta})-\rho(0, \bar{\theta}) .
\end{aligned}
$$

Additional effort increases the probability of success. Assuming complementarity of effort and ability, the increase is stronger for a high-ability agent than for a low-ability agent. If no additional effort is exerted, a high-ability agent has still a positive probability of success while the success probability of a low-ability agent is normalized to zero. ${ }^{8}$ 
We distinguish between the agent's measured output $Q$ and the non-contractible value $S$ of that output to the principal (see also Baker 1992). Building from Laffont and Martimort (2002: chapter 9), we assume that the value of the agent's output for the principal depends directly on the agent's type:

$$
S(\theta, Q)=\left\{\begin{array}{c}
\gamma Q \text { if } \theta=\bar{\theta} \\
0 \text { if } \theta=\underline{\theta}
\end{array}\right.
$$

with $\gamma>0$. The parameter $\gamma$ is assumed to be sufficiently large so that it is profitable for the employer to hire a high-ability agent. Equation (3) reflects the principal's hiring problem. The equation implies that it has only value for the principal to hire a high-ability agent, but not to hire a low-ability agent. Even if a low-ability agent exerts effort and produces a positive output $q$ with probability $\rho(1, \underline{\theta})$, the value of that output to the principal is equal to zero. One possible interpretation of equation (3) is that some minimum quality is required to make the output valuable to the principal. The output of a high-ability agent meets this quality standard while the output of a low-ability agent does not meet it. ${ }^{9}$ Thus, it has no value for the principal to hire a low-ability agent. Agents are risk-neutral and their utility functions are given by

$$
U(W, e)=W-C(e)
$$

where $W$ is the wage and $C(e)$ the disutility of effort with $C(0)=0$ and $C(1)=c>0$. The principal can either pay a time rate $W=\bar{W}$ or a performance-related wage. We assume that the agent's effort $e$ is not observable by the principal. As the value $S$ of the output to the principal is not contractible, performance pay can only be based on the agent's output $Q$.

Agents are assumed to be protected by limited liability implying that they must receive a non-negative wage regardless of whether the project is successful or not: $W \geq 0$. As a consequence, a performance pay contract specifies a payment $W=\alpha Q$ where $\alpha$ is the agent's 
share in produced output. Designing performance pay and verifying produced output is costly to the principal. Thus, performance pay entails a cost $m>0$. Furthermore, we assume that

$$
\bar{U}<\frac{\rho(0, \bar{\theta}) c}{\rho(1, \bar{\theta})-\rho(0, \bar{\theta})} .
$$

In contrast to standard principal-agent models, a model with limited liability can imply that exerting effort under performance pay involves a rent for the agent. However, as emphasized by Macho-Stadler and Perez-Castrillo (2017), this requires that the agent's reservation utility is not too high. ${ }^{10}$ Assumption (5) means that the reservation utility of a high-ability agent is sufficiently low so exerting effort under (high-powered) performance pay yields an expected utility greater than this reservation utility.

The timing is as follows: The principal chooses a hiring strategy and announces the contract. Agents decide whether or not they apply for the position. The principal hires an agent. The agent chooses effort. Output is realized.

\subsection{The Principal's Hiring Strategies}

The principal chooses among three hiring strategies, namely applicant screening coupled with a time rate, low-powered performance pay, and high-powered performance pay.

Applicant screening coupled with a time rate. If the principal pays a time rate, there is no incentive for an agent to exert effort. Thus, there is no disutility of effort the agent must be compensated for. To attract $\bar{\theta}$-agents, the principal sets the time rate equal to their reservation utility: $\bar{W}=\bar{U}$. However, this wage alone entails an adverse selection problem. Agents with low ability $\underline{\theta}$ have also an incentive to apply for the job, as their reservation utility $\underline{U}$ is smaller than the reservation utility $\bar{U}$ of $\bar{\theta}$-agents.

To avoid such adverse selection, the principal combines the wage offer with the 
announcement that applicants will be screened. Screening discourages $\underline{\theta}$-agents from applying for the job. They anticipate that they have no chance of being hired, as their true type will be revealed. Hence, the pool of applicants only consists of $\bar{\theta}$-agents. Even though the principal has rational expectations about the type of the applicants, the credibility of the announcement requires that she screens applicants. As all of the applicants are $\bar{\theta}$-agents, the principal has to screen only one applicant. She hires the first applicant who is screened. The principal's expected profit is:

$$
E \Pi_{1}=E[S]-\bar{W}-z=\rho(0, \bar{\theta}) \gamma q-\bar{U}-z
$$

Applicant screening ensures that the vacant position is filled with an agent of type $\bar{\theta}$. The $\bar{\theta}$ agent produces output $q$ with probability $\rho(0, \bar{\theta})$. This output has a value $\gamma q$ for the principal. However, the principal not only incurs wage cost $\bar{W}$, but also the additional screening cost $z$.

High-powered performance pay. High-powered performance pay not only induces a selfsorting of agents, but also provides incentives to exert additional effort. An agent exerts additional effort if the expected utility from exerting effort is at least as large as the expected utility from exerting no effort:

$$
\rho(1, \theta) \alpha q-c \geq \rho(0, \theta) \alpha q
$$

The minimum share $\alpha$ that induces an agent of type $\bar{\theta}$ to exert effort is:

$$
\alpha^{*}=\frac{c}{(\rho(1, \bar{\theta})-\rho(0, \bar{\theta})) q} .
$$

The resulting expected utility of the $\bar{\theta}$-agent is equal to the expected wage minus the disutility of effort:

$$
E U^{*}=\rho(1, \bar{\theta}) \alpha^{*} q-c=\frac{\rho(0, \bar{\theta}) c}{\rho(1, \bar{\theta})-\rho(0, \bar{\theta})}
$$


High-powered performance pay attracts $\bar{\theta}$-agents if

$$
E U^{*} \geq \bar{U}
$$

Assumption (5) implies that inequality (10) holds. This is in line with empirical research showing that workers on performance pay receive a rent in terms of higher job satisfaction (Cornelissen et al. 2011). ${ }^{11}$

For $\underline{\theta}$-agents, the share $\alpha^{*}$ is too small to induce effort. Taking (2c) and (8) into account, we obtain $(\rho(1, \underline{\theta})-\rho(0, \underline{\theta})) \alpha^{*} q<c=(\rho(1, \bar{\theta})-\rho(0, \bar{\theta})) \alpha^{*} q$. As the effort of $\underline{\theta}$-agents increases the success probability to a smaller amount than the effort of $\bar{\theta}$-agents, the increase in the expected earnings of $\underline{\theta}$-agents is not large enough to offset their disutility of effort. The $\underline{\theta}-$ agents' expected utility from exerting effort is smaller than their expected utility from exerting no effort.

Taking into account that $\underline{\theta}$-agents exerting no effort have zero success probability, their expected utility from high-powered performance pay equals zero. This utility is smaller than their reservation utility $\underline{U}$. Thus, $\underline{\theta}$-agents are discouraged by high-powered performance pay from applying for the job. This implies that the principal hires a $\bar{\theta}$-agent for sure. The principal's expected profit is $E \Pi_{2}=\rho(1, \bar{\theta}) \gamma q-\alpha^{*} \rho(1, \bar{\theta}) q-m$. Taking (9) into account, the expected profit can be rewritten:

$$
E \Pi_{2}=\rho(1, \bar{\theta}) \gamma q-\left(E U^{*}+c\right)-m
$$

High-powered performance pay not only attracts $\bar{\theta}$-agents, but also provides incentives to exert additional effort. Thus, compared to applicant screening, high-powered performance pay has the advantage that it implies a higher success probability $\rho(1, \bar{\theta})$. The disadvantage is that it entails a higher expected wage $E[W]=\left(E U^{*}+c\right)$ and the monitoring cost $m$.

Low-powered performance pay. Low-powered performance pay is only used to attract $\bar{\theta}$ - 
agents, but not to induce additional effort. The principal sets the share $\alpha$ in such a way that, for $\bar{\theta}$-agents, the expected utility is equal to their reservation utility: $\alpha \rho(0, \bar{\theta}) q=\bar{U}$. This yields

$$
\alpha^{* *}=\frac{\bar{U}}{\rho(0, \bar{\theta}) q} .
$$

Taking (9) and (10) into account, it is straightforward to show that $\alpha^{* *}<\alpha^{*}{ }^{12}$ As $\alpha^{*}$ is the minimum share providing an incentive for high-ability agents, this means that $\alpha^{* *}$ is too low to induce effort. If $\alpha^{* *}$ does not provide an incentive for $\bar{\theta}$-agents, it also does not provide an incentive for $\underline{\theta}$-agents. As $\underline{\theta}$-agents have zero success probability when exerting no effort, they would receive zero expected utility if they were on low-powered performance pay. That utility is smaller than their reservation utility $\underline{U}$. Thus, $\underline{\theta}$-agents are discouraged by low-powered performance pay from applying for the job. The principal's expected profit is:

$$
E \Pi_{3}=\rho(0, \bar{\theta}) \gamma q-\alpha^{* *} \rho(0, \bar{\theta}) q-m=\rho(0, \bar{\theta}) \gamma q-\bar{U}-m .
$$

The principal hires a high-ability agent who exerts no effort. This implies a success probability of $\rho(0, \bar{\theta})$. The principal pays an expected wage equal to the high-ability agent's reservation utility $\bar{U}$ and incurs the monitoring cost $m$.

Comparing the hiring strategies. The principal chooses the hiring strategy that yields the highest expected profit. The choice depends on the wage cost (the agent's rent and the compensation for the agent's disutility when inducing additional effort), the monitoring cost, the screening cost, and the success probabilities with and without additional effort (see Appendix A for details).

The basic point for our analysis is that, in our model with one-dimensional ability of the agents, screening and performance pay are substitutes. Applicant screening is only required if the principal pays a time rate. It is not required if the principal uses performance pay. This applies to 
both high-powered and low-powered performance pay. High-powered performance pay solves both the moral hazard and the adverse selection problem. It provides incentives for high-ability agents to exert effort and discourages low-ability agents from applying for the job. Low-powered performance pay only solves the adverse selection problem. It discourages low-ability agents from applying for the job, but provides no incentive for high-ability agents to exert effort.

\subsection{Model Extension: Multitasking}

To capture multitasking, we now assume that ability is two-dimensional. Let $\eta \in\{\underline{\eta}, \bar{\eta}\}$ denote an agent's second ability where a low-ability agent is characterized by $\underline{\eta}$ and a high-ability agent by $\bar{\eta}$. The share of $\bar{\eta}$-agents in the population is given by $\mu$. Ability $\eta$ may reflect innovativeness, flexibility, customer service skills, or specific quality skills. The second ability is also not immediately observable to the principal. But the principal can invest in screening to unambiguously identify this ability. Identifying an agent's second ability entails a fixed cost $k>0$. The two abilities $\theta$ and $\eta$ may be correlated, but are not perfectly correlated.

If production is characterized by multitasking, the principal values both the first and the second ability. Both dimensions are additively separable: $S(\theta, Q)+V(\eta)$, where $S(\theta, Q)$ is given by equation (3) and $V(\eta)$ is the value of the agent's second ability to the principal:

$$
V(\eta)=\left\{\begin{array}{l}
v>0 \text { if } \eta=\bar{\eta}, \\
0 \text { if } \eta=\underline{\eta}
\end{array}\right.
$$

The value $V(\eta)$ to the principal is not verifiable. Thus, performance pay can still only be based on the output $Q$ of the first performance dimension. As to the second dimension of ability, we focus on the adverse selection problem and abstract from moral hazard. ${ }^{13}$ All of our previous assumptions remain valid. Specifically, we assume that reservation utilities only depend on the 
agents' first ability $\theta$.

We now distinguish between applicant screening coupled with a time rate, low-powered performance pay, high-powered performance pay without applicant screening, and high-powered performance pay combined with applicant screening. We show that low-powered performance pay and screening the first ability of applicants do not involve an adverse selection problem with respect to the second ability. However, high-powered performance pay entails such problem because of the rent an agent receives under this incentive scheme. Thus, the principal must decide whether or not to combine high-powered performance pay with additional applicant screening.

Low-powered performance pay and applicant screening coupled with a time rate. If the principal screens applicants with respect to $\theta$ or uses low-powered performance pay for output $Q, \underline{\theta}$-agents are still discouraged from applying for the job regardless of whether they are of type $\bar{\eta}$ or type $\underline{\eta}$. The $\bar{\theta}$-agents are still willing to apply for the job. They receive a utility equal to their reservation utility when they work for the principal. The second ability $\eta$ has no influence on that utility. Thus, applicants do not have an incentive to mask their true ability $\eta .{ }^{14}$ They realize their reservation utility regardless of whether or not they are hired by the principal. Thus, the principal can simply ask applicants to reveal their true ability $\eta \cdot{ }^{15}$ She then chooses an applicant with ability $\bar{\eta}$. If the principal screens applicants with respect to $\theta$, her expected profit is

$$
E \Pi_{4}=E \Pi_{1}+v
$$

The principal's expected profit from low-powered performance pay is

$$
E \Pi_{5}=E \Pi_{3}+v
$$

Even though the principal screens applicants only with respect to the first ability $\theta$ or provides low-powered rewards only for the output associated with $\theta$, she is able to hire an agent with a 
high ability $\bar{\eta}$ and to realize the full value of multitasking. No additional screening with respect to the second ability $\eta$ is required.

High-powered performance pay without applicant screening. If the principal provides high-powered performance pay, agents with ability $\bar{\theta}$ receive an expected utility $E U^{*}$ greater than their reservation utility $\bar{U}$. Because of the limited liability constraint, the principal must leave a rent to agents when inducing effort in the first performance dimension. Thus, $\bar{\theta}$-agents apply for the job regardless of whether they are $\bar{\eta}$-types or $\eta$-types. High-powered rewards for output associated with the first ability involve an adverse selection problem with the respect to the second ability, as even $\underline{\eta}$-types apply for the job. The $\underline{\eta}$-types have an incentive to mask their true type and to pretend that they are $\bar{\eta}$-types. If the principal does not screen with respect to $\eta$, she randomly hires one of the applicants. Her expected profit is

$$
E \Pi_{6}=E \Pi_{2}+\mu(\bar{\eta} \mid \bar{\theta}) v
$$

where $\mu(\bar{\eta} \mid \bar{\theta})$ is the conditional probability that the hired agent is of type $\bar{\eta}$ given that the agent is a $\bar{\theta}$-type. The principal realizes the value $v$ of multitasking only with probability $\mu(\bar{\eta} \mid \bar{\theta})$.

High powered performance pay coupled with applicant screening. If the principal provides high-powered performance pay and screens applicants with respect to $\eta$, she can discourage $\underline{\eta}$-types from applying for the job. These types anticipate that they have no chance of being hired, as screening will reveal their true type. Hence, combining performance pay with applicant screening implies that only workers who have a high ability in both performance dimensions apply for the job. While high-powered performance pay attracts $\bar{\theta}$-agents, applicant screening ensures that only those agents who are also of type $\bar{\eta}$ apply for the job. Thus, the principal can hire the first applicant who is screened. Her expected profit is 


$$
E \Pi_{7}=E \Pi_{2}+v-k
$$

The principal hires an agent of type $\bar{\eta}$ for sure. However, this entails the screening cost $k$. The principal combines high-powered performance pay with screening if the screening cost is smaller than the expected loss from hiring an agent of type $\underline{\eta}: k \leq 1-\mu(\bar{\eta} \mid \bar{\theta}) v$.

Comparing the hiring strategies. Low-powered performance pay and applicant screening with respect to the first ability have the advantage that they entail no adverse selection with respect to the agents' second ability. Both hiring strategies allow realizing the full value of multitasking without incurring further cost. By contrast, high-powered performance pay involves an adverse selection with respect to the second ability. Agents whose first ability is high can realize a utility greater than their reservation utility. Thus, they have an incentive to apply for the job regardless of whether their second ability is high or low. This is costly to the principal, as she either has a lower (expected) value from the agent's multitasking or has to screen applicants with respect to the second ability. Thus, if production is characterized by multitasking, the principal's propensity to use high-powered performance pay is reduced. She chooses high-powered performance pay only if the additional effort induced by this pay scheme yields a sufficiently large increase in expected output that also outweighs the additional disadvantages resulting from the new adverse selection problem associated with the unobservable performance dimension.

Most importantly in our context, the new adverse selection problem can imply that a principal using high-powered performance pay additionally invests in applicant screening. Thus, high-powered performance pay and applicant screening may be complements if production is characterized by multitasking. This should specifically hold if the value $v$ of the agent's multitasking is high and the principal faces a high probability $1-\mu(\bar{\eta} \mid \bar{\theta})$ that agents with low multitasking ability apply for the job. 


\subsection{Implications for the Empirical Analysis}

In our empirical analysis, we do not distinguish between the various dimensions on which applicants are screened, but rather consider the total intensity of applicant screening. The implications of our theoretical model for the intensity of applicant screening can be summarized as follows (see also Appendix A).

If production is characterized by a single-dimensional task or multitasking is not substantial $(k>1-\mu(\bar{\eta} \mid \bar{\theta}) v)$, there is a clear negative relationship between performance pay and applicant screening. The principal invests an amount $z$ in applicant screening when paying a time rate, but does not invest in applicant screening when using low-powered or high-powered performance pay.

If production is characterized by multitasking and multitasking has a substantial value to the principal $(k \leq 1-\mu(\bar{\eta} \mid \bar{\theta}) v)$, the principal invests in applicant screening when using highpowered performance pay. This means that substantial multitasking weakens the negative relationship between performance pay intensity and applicant screening or may even result in a positive relationship. If the amount $k$ invested in case of high-powered performance pay is smaller than the amount $z$ invested in case of a time rate, the relationship between performance pay intensity and applicant screening would be still negative, but weaker than under singletasking conditions. If $k$ is greater than $z$, the relationship between intensity of performance pay and intensity of applicant screening is positive. In our screening regressions, the coefficient on performance pay intensity should take a negative sign while the coefficient on the interaction of performance pay intensity and multitasking should take a positive sign. If the relationship between performance pay intensity and applicant screening is positive under multitasking, we should find that the latter coefficient dominates the first one. If multitasking only weakens the 
negative relationship, the latter coefficient should not dominate.

\section{Alternative Methods of Performance Measurement}

\subsection{Performance Appraisals}

The relationship between performance pay and applicant screening may not only depend on the nature of production, but also on how individual worker performance is measured. Performance measures can be either objective or subjective (Baker et al. 1988). Objective measures such as sales or the quantity of produced output involve a relatively low degree of discretion and can be easily verified. In contrast, subjective performance measures such as performance appraisals by superiors are based on judgments and opinions that are often not verifiable and involve a high degree of discretion.

A potential drawback of objective performance measures is that they capture only a limited set of performance dimensions. Many dimensions of individual worker performance such as cooperativeness, customer orientation, leadership behavior, flexibility, and creativity are difficult to verify objectively. However, these performance dimensions can be assessed by subjective performance appraisals. Thus, a measurement of individual worker performance that also involves subjective appraisals provides a more comprehensive approach of performance measurement.

Such comprehensive measurement of performance appears to be specifically important in a multitask setting that involves complex performance dimensions (Jirjahn and Poutsma 2013, Prendergast 1999). The potential comprehensiveness of performance appraisals may have implications for the relationship between performance pay and applicant screening. It reduces the need for intensive screening so that, in a multitask setting, the complementary relationship between performance pay and applicant screening may be less strong for firms using 
performance appraisals. In the extreme, if subjective appraisals capture all relevant performance dimensions, a substitutive relationship between performance pay and applicant screening might even hold for a high degree of multitasking. In that case, multitasking would only lead to a complementary relationship if narrow objective performance measures are used.

However, there is a second effect of performance appraisals working in the opposite direction. Performance appraisals entail a high degree of subjectivity (Prendergast and Topel 1993). This allows workers to strategically engage in influence activities that result in a positive evaluation, but not necessarily in increased performance (Acemoglu et al. 2008, Milgrom and Roberts 1988). Workers may conform to the opinion of their superiors or provide flattery and private services to the superiors. If workers are heterogeneous in their ability to engage in such activities, performance appraisal systems may attract those workers who have a special talent for manipulating their superiors' evaluations. Thus, employers using performance appraisal systems have an incentive to carefully screen applicants in order to avoid such adverse self-sorting. ${ }^{16}$

Altogether, the use of a performance appraisal system can influence the relationship between performance pay and screening in two opposite ways. On the one hand, performance appraisals provide a more comprehensive measurement of worker performance so that the employer's need for applicant screening is reduced even if production is characterized by multitasking. On the other hand, performance pay based on subjective performance measures can entail an adverse self-sorting of workers who have a high talent for engaging in unproductive influence activities. In order to mitigate this problem, employers have to screen applicants.

\subsection{Collective Incentives}

Performance cannot only be measured at the individual level, but also at the group or firm level. Thus, collective incentive schemes such as group performance pay or profit sharing stand as 
alternatives to provide incentives for multitasking (Baker 2002, Jirjahn 2001). Specifically, profit sharing rewards all worker activities and worker characteristics relevant for the firm's profit. Thus, profit sharing may not only provide incentives to adequately allocate effort across all tasks needed for production. It may also attract those workers whose skills and abilities match the various job requirements. This would reduce the need for intensive applicant screening.

However, profit sharing, like other collective incentive schemes, suffers from a free rider problem. The incentive to exert effort dissipates as the returns to that effort are distributed among all workers participating in the profit sharing scheme. Under certain circumstances, mutual monitoring and peer pressure may help mitigate the free rider problem (Kandel and Lazear 1992). This solution requires that the employer hires the right types of workers (Cornelissen et al. 2014). There appear to be two types of workers who may not have the appropriate personality traits to overcome the disincentives associated with profit sharing. On the one hand, profit sharing may attract talented free riders who are not responsive to social pressure. On the other hand, workers with too strong negative reciprocal inclinations may exert excessive peer pressure resulting in reduced cooperation and unproductive conflicts. Thus, the employer has to invest in increased applicant screening to select workers who are responsive to social pressure and are willing to exert peer pressure without having an excessively high degree of negative reciprocal inclination.

To summarize, the relationship between profit sharing and applicant screening is ambiguous. On the one hand, profit sharing provides a comprehensive reward for the skills needed for production. This may induce a positive self-sorting of workers whose skills match the various job requirements. If this effects dominates, there will be a substitutive relationship even in a multitask setting. On the other hand, profit sharing entails a free rider problem that can only 
be mitigated if the employer invests in applicant screening to hire workers with the appropriate team skills. If that effect dominates, we will observe a complementary relationship.

\section{Data and Variables}

\subsection{Data Set}

The data used in our empirical analysis are based on an additional survey of a subsample of establishments participating in the IAB Establishment Panel. The IAB Establishment Panel is a representative sample of establishments from all sectors in the German economy (Fischer et al. 2009). Infratest Sozialforschung, a professional survey and opinion research institute, conducts the interviews on behalf of the Institute for Employment Research (IAB). The data are collected on the basis of a questionnaire and follow-up personal interviews with the owner or top manager of the establishment. Each year since 1993 (1996), the IAB Establishment Panel has surveyed establishments in West (East) Germany.

The additional survey was conducted in the 2012 wave (Kampkoetter et al. 2016). This add-on survey, the Linked Personnel Panel (LPP), consists of a questionnaire for the employer and a questionnaire for the employees. The employer questionnaire, answered by the owner or top managers of the establishment, has a specific focus on topics related to HRM including hiring and performance management. The employee questionnaire asks about job characteristics, and the interviewee's socio-demographic background.

We mainly use the employer survey of the LPP. The survey is a representative sample of private sector establishments with 50 or more employees in manufacturing and service industries. The sample is stratified according to establishment size classes (50-99, 100-249, 250499, and 500 and more employees), industries (metalworking and electronic industries, further manufacturing industries, retail and transport, services for firms, and information and 
communication services) and regions (North, East, South, and West Germany). We include variables for the stratification characteristics in the estimations so we need not use weights (Winship and Radbill 1994).

While the IAB Establishment Panel comprises interviews with 15,556 establishments, the LPP data are based on a subsample of 1,219 establishments. After eliminating observations for which full information is not available, the analysis on the screening of non-managerial applicants is based on data from 1,036 establishments. For the analysis on the screening of managerial applicants, information is available from 915 establishments.

In order to examine if our establishment-level indicator of multitasking is indeed associated with higher task variety at the individual level, we also use the employee data of the LPP. 7,508 employees in 861 establishments participated in the survey. 82.5 percent of the employees agreed that their data are matched with the establishment data. Thus, linked employer-employee data are available for 6,195 employees. After removing observations with missing values, we have data from 5,409 employees in 788 establishments for our examination.

\subsection{Applicant Screening}

Table 1 provides the definitions and descriptive statistics of variables. Our dependent variable is the intensity of applicant screening, measured as the time usually taken for the screening of an applicant. ${ }^{17}$ This information is provided for both managerial and non-managerial applicants. On average, the establishments in our sample spend 320 minutes of screening per managerial applicant and 166 minutes per non-managerial applicant.

Table B.1 in Appendix B shows that the distribution of the logarithm of the dependent variable is closer to the normal distribution than the distribution of the level. The skewness is much closer to 0 and the kurtosis is much closer to 3 . Thus, we mainly use the log of the 
intensity of applicant screening Nonetheless as a robustness check, we also present regressions using the level.

\subsection{Individual-Based Performance Pay}

The key explanatory variable is the average percentage share of individual-based performance pay in relation to the employees' base pay. ${ }^{18}$ While studies on performance pay are often based on simple dummy variables, this variable provides a more nuanced measurement as it captures differences in the intensity of performance pay across establishments. Information on performance pay is available for managerial and non-managerial employees. Considering all establishments, the mean is 3.7 percent for managerial employees and 3.2 percent for nonmanagerial employees. Considering only establishments with individual performance pay, the means are 8.6 and 9.1 percent. Note that 43 percent of the establishments use performance pay for managerial employees while 35 percent use performance pay for non-managerial employees.

\subsection{Multitasking}

Our theoretical considerations suggest that the relationship between performance pay and applicant screening depends on the degree of multitasking. In order to capture increased multitasking in the empirical analysis, we use information on the establishment's business model. Interviewees had to choose one item from a list of possible strategies to characterize the establishment's primary business model. We define a dummy variable equal to 1 if the establishment's business model is primarily characterized by high quality, innovativeness or customer-specific solutions. The reference group consists of establishments with a price strategy or 'other' strategies.

The literature has identified quality orientation, innovativeness and customer-specific 
production as involving an increased degree of multitasking. The allocation of effort and talent across the quantitative and qualitative dimension of performance is the classic example in the multitasking literature (Holmstrom and Milgrom 1991). If the market strategy has a focus on high quality, the employer must ensure that workers do not increase individual output at the expense of product quality. Innovativeness entails increased multitasking as workers do not only have to perform their standard tasks, but also have to engage in innovative activities (Hellmann and Thiele 2011, Morita 2005). Innovativeness requires that workers are flexible to switch from one task to another. Askildsen et al. (2006), Jirjahn and Kraft (2011) and Laursen and Foss (2003) confirm that innovativeness is associated with indicators of multitasking such as flexible production, further training, and the use of production teams with expanded involvement in decision making and increased responsibilities. This suggests that innovativeness involves multifaceted tasks not only for R\&D employees, but also for a broader group of employees within the establishment. Similarly, a market strategy focusing on the varying and specific needs of customers entails that workers have to perform a wider spectra of tasks (Griffith and Neely 2009, Lindbeck and Snower 2000). This also involves greater interaction with customers in order to build reputation and customer goodwill.

\subsection{Control Variables}

In the regressions, we account for performance appraisals. Performance appraisals may not only be used in allocating financial rewards, but also in providing feedback to workers, in making job assignment, and in determining training needs (Heywood et al. 2017). Thus, performance appraisal use does not perfectly overlap with the use of performance pay. We include a dummy equal to 1 if the firm uses performance appraisals and recommends a predetermined distribution of ratings that evaluators have to follow. Recommended distributions are adopted to ensure more 
differentiation among employees (Kampkoetter and Sliwka 2016). The variable for performance appraisals is available for both managerial and non-managerial employees. In the course of the analysis, we will interact the performance appraisal variable with the variables for performance pay and multitasking to examine if the moderating role of multitasking differs between firms with and without performance appraisal systems.

To contrast individual performance pay with collective performance pay, we include variables for the average percentage shares of group performance pay and profit sharing in relation to the employees' base pay. In the course of the analysis, we will not only examine interactions of the various payment schemes with the multitasking indicator, but also interactions of the payment schemes among each other. Some recent studies have addressed the question of whether or not multiple incentive schemes should be combined (Barnes et al. 2011, Jirjahn 2018, Pendleton 2006, Pendleton and Robinson 2015).

We also take into account that the quality of matches between workers and jobs is more important to establishments with higher skill requirements (DeVaro 2005). Thus, these establishments should be characterized by a higher screening intensity. Skill requirements are captured by the vintage of production technology, the share of employees with completed apprenticeship training and the share of employees with university degree.

Variables for industrial relations are also included in the regressions. Industrial relations in Germany are characterized by a dual structure of worker representation with both unions and works councils (Huebler and Jirjahn 2003). Unions usually negotiate collective bargaining contracts on an industrial level. Employers are covered by those contracts if they are members of an employers' association. Works councils provide a highly developed mechanism for codetermination at the establishment level. The incidence of a works council depends on the 
initiative of the workforce. Collective bargaining coverage and works councils have been shown to encourage internal labor markets resulting in higher tenure with the employer (Heywood et al. 2010, Zwick 2011). Firms should screen applicants more intensively if they foster long-term employment relationships.

Furthermore, establishment size should play a role. Larger establishments are more able to implement internal labor markets. Moreover, they may be more likely to have a professional personnel management helping adopt effective screening procedures. We also include a dummy equal to 1 if personnel management is embedded at the top management level. This variable indicates the importance the establishment places on personnel issues. General establishment characteristics are controlled for by variables for foreign owners, owner-managers, legal form, and the share of women. Finally, we include industry and region dummies.

\section{Estimation Results}

\subsection{Screening of Non-Managerial Applicants}

Table 2 shows the results on the determinants of the screening intensity for non-managerial applicants. Regression (1) does not account for the interaction of non-managerial performance pay and multitasking while regressions (2) includes an interaction term. Several of the control variables emerge with significant coefficients. The share of university graduates, works councils incidence, profit sharing, and use of performance appraisals are positively associated with screening intensity.

Turning to the key explanatory variable, non-managerial performance pay takes a significantly positive coefficient in regression (1). This would suggest that performance pay and screening intensity are complements. However, as shown by regression (2), the relationship between performance pay and the intensity of screening crucially depends on the extent of 
multitasking. When including the interaction of performance pay and multitasking, performance pay takes a significantly negative coefficient while the interaction term emerges with a significantly positive coefficient. The estimated coefficients imply that the intensity of performance pay is a negative determinant of the intensity of applicant screening if there is no increased multitasking $(-0.021+0.027 \times 0=-0.021)$. By contrast, the intensity of performance pay is positively associated with the intensity of applicant screening if production is characterized by increased multitasking $(-0.021+0.027 \times 1=0.006)$.

For a quantitative assessment, let us consider an 8 percentage point increase in the share of performance pay. This is roughly an increase by one standard deviation. The one standard deviation increase in the share of performance pay implies a decrease in the intensity of applicant screening by 17 percent in a firm without increased multitasking $(-0.021 \times 8=-0.168)$. It implies an increase by 5 percent in a firm with increased multitasking $(0.006 \times 8=0.048)$.

Thus, our estimates confirm that the relationship between performance pay and screening of non-managerial applicants is moderated by the nature of production. If production is characterized by a low degree of multitasking, performance pay and applicant screening are substitutes. An employer tying pay tightly to individual performance does not need extensive applicant screening. Performance pay attracts workers who have high abilities in the rather simple tasks. However, if production is characterized by a higher degree of multitasking, performance pay and applicant screening are complements. The self-sorting process induced by performance pay does not necessarily guarantee a high quality of matches between workers and jobs. In a multitask setting, performance measures are often not available for all of the relevant tasks so that performance pay may attract workers who are only strong in the measured performance dimensions, but are weak in the non-measured dimensions. Hence, employers tying 
performance tightly to individual performance in a multitask setting screen applicants more extensively to mitigate such problems.

\subsection{Screening of Managerial Applicants}

Table 3 presents results on the determinants of the screening intensity for managerial employees. The key explanatory variable is now the intensity of managerial performance pay. In contrast to the estimates for non-managerial employees, profit sharing, the use of performance appraisals and the share of university graduates do not emerge with significant coefficients. However, the incidence of a works council plays also a significant role in the screening intensity for managerial employees. Moreover, establishment size and collective bargaining coverage now take significantly positive coefficients.

Turning to our key explanatory variable, the coefficient on performance pay is insignificant in the initial regression (1) that does not account for the interaction with multitasking. However, taking the interaction into account, the estimations for managerial employees repeat the crucial pattern of results found for non-managerial employees. In regression (2), performance pay emerges with a significantly negative coefficient while the interaction term takes a significantly positive coefficient. The negative coefficient of the performance pay variable is dominated by the positive coefficient of the interaction term. Thus, the intensity of performance pay is associated with a reduced intensity of applicant screening only if there is no increased multitasking $(-0.025+0.032 \times 0=-0.025)$. It is associated with a greater intensity of applicant screening if production is characterized by increased multitasking ($0.025+0.032 \times 1=0.007)$. Hence, also the estimates for managerial employees confirm that the relationship between performance pay and applicant screening crucially depends on the nature of production. 
For a quantitative assessment, we again consider an 8 percentage point increase in the share of performance pay. The increase in the share of performance pay is associated with a decrease in the intensity of screening managerial applicants by 20 percent if there is no increased multitasking $(-0.025 \times 8=-0.200)$. It implies an increase in the screening intensity by 6 percent if there is increased multitasking $(0.007 \times 8=0.056)$. All in all, the key results are very similar for the screening of managerial and non-managerial applicants.

\subsection{Separate Estimates}

We also ran separate estimations for establishments with and without increased multitasking. As shown in Table B.2, the separate estimates confirm our key results. They show a significantly positive association between performance pay and applicant screening for establishments with increased multitasking and a significantly negative association for establishments without increased multitasking. This holds for both managerial and non-managerial employees.

\subsection{Interactions with Collective Incentive Schemes}

We return to the combined sample of establishments and additionally consider interactions of multitasking with profit sharing and group-based performance pay to examine if a similar pattern of results can also be found for collective incentive schemes. Moreover, we account for various combinations of incentive schemes to analyse if collective incentive schemes complement individual-based performance pay especially in a multitask environment.

Table 4 shows the results. While the estimates confirm the key results for individualbased performance pay, virtually all of the coefficients on the other interaction terms are insignificant. Collective incentive schemes involve two opposing effects on the need for applicant screening. On the one hand, these schemes reduce the need for intensive applicant 
screening, as they provide a more comprehensive reward for the worker characteristics relevant to firm's production. On the other hand, collective incentive schemes can entail an increased need for applicant screening, as firms must invest in finding workers with appropriate team skills to mitigate the free rider problem. The results indicate that the two opposing effects largely offset each other. The estimates provide only some evidence that, in a multitask environment, a combination of group-based performance pay and profit sharing reduces the intensity of applicant screening for managers.

Altogether, the key results on individual-based performance pay are confirmed when additionally taking interactions with collective schemes into account. Moreover, we find no evidence that collective incentives moderate the relationship between individual-based performance pay and applicant screening.

\subsection{Interactions with Performance Appraisals}

Next we examine if the relationship between individual-based performance pay and applicant screening depends on how worker performance is measured. We include additional interactions with the performance appraisal dummy. Performance appraisals provide a more comprehensive measurement of worker performance. This may reduce the need for intensive applicant screening. However, performance appraisal systems can generate their own problems if they attract workers who are talented in manipulating the process of appraisal to their advantage. This increases the need for an intensive applicant screening in order to mitigate the problem of adverse self-sorting. Thus, performance appraisals can influence the relationship between performance pay and applicant screening in opposite ways.

Table 5 shows the key results. The positive coefficient on the performance appraisal dummy is now also significant in the regression for managerial employees. However, the 
additional interaction effects do not emerge with significant coefficients in that regression. Most importantly, the regression confirms our key results. The association between individual-based performance pay and screening intensity is negative in establishments without increased multitasking and positive in establishments with increased multitasking.

In the regression for non-managerial employees, the additional interaction variables take significant coefficients. Thus, the relationship between performance pay and the screening of non-managerial employees is influenced by the employer's use of performance appraisals. In a setting without increased multitasking, the negative link between performance pay and screening is stronger for establishments using performance appraisals $(-0.019+0.027 \times 0-0.383 \times 1+$ $0.376 \times 1 \times 0=-0.402)$ than for establishments not using performance appraisals $(-0.019+0.027$ x $0-0.383 \times 0+0.376 \times 0 \times 0=-0.019$ ). In a setting with increased multitasking, the positive link between performance pay and screening is less strong for establishments with a performance appraisal system $(-0.019+0.027 \times 1-0.383 \times 1+0.376 \times 1 \times 1=0.006)$ than for establishments without such a system $(-0.019+0.027 \times 1-0.383 \times 0+0.376 \times 0 \times 1=0.008)$. These findings suggest that a comprehensive measurement of worker performance reduce the need for intensive screening of applicants. However, the base effect of performance appraisal use on screening intensity is positive in both the setting without increased multitasking $(0.820-0.590 \times 0=$ $0.820)$ and the setting with increased multitasking $(0.820-0.590 \times 1=0.230)$. This indicates that establishments using performance appraisals undertake some base investment in applicant screening to mitigate the adverse self-selection of workers who have a high talent for unproductive influence activities.

To summarize, our key results are confirmed even when taking potential interactions with the employer's use of performance appraisals into account. There is a negative association 
between individual-based performance pay and screening intensity in establishments without increased multitasking and a positive one in establishments with increased multitasking. For managerial employees, the estimates provide no evidence that the use of performance appraisals plays a moderating role. For non-managerial employees, the estimates suggest that performance appraisals influence the strength of the association, but without reversing its sign.

\subsection{The Multitasking Indicator}

Our dummy for multitasking captures three different business models. As a robustness check, we divide this combined variable into three separate dummies with each dummy capturing one of the three business models. As shown in Table B.3, we find for each business model a significantly positive interaction with performance pay. This underscores that innovativeness, quality orientation and customer orientation, in a similar way, reflect increased multitasking.

Furthermore, we use the linked employer-employee data to examine if our establishmentlevel indicator of multitasking is indeed associated with increased task variety at the individual job level. The employee survey provides information on the variety of tasks an employee performs on the job. Employees respond to the statement "In my job I perform very different tasks" on a five-point Likert scale ranging from 1 "applies completely" to 5 "does not apply at all". We recode this variable in inverse order so that higher scale points reflect a higher degree of task variety.

Table 6 presents ordered probit estimations on the determinants of task variety. Regression (1) only includes the establishment-level dummy for multitasking. The dummy takes a significantly positive coefficient suggesting that our establishment-level indicator of multitasking is indeed associated with higher task variety at the individual job level. In regression (2), we additionally include a series of employee variables (see Table B.4 for 
definitions and descriptive statistics). The employee's age, a university degree and the number of weekly working hours are positive covariates of task variety while a blue-collar job is a negative covariate. This regression also confirms a positive association between the establishment-level indicator of multitasking and tasks variety at the individual job level. In regression (3), we add a series of establishment-level variables to the specification. Works council incidence is negatively and the share of women positively linked to task variety. The establishment-level dummy for multitasking remains a significantly positive determinant of task variety.

In regression (3) to (6), we replace the multitasking indicator by dummy variables for the three business models. In each of these regressions, the dummy variables for the business models take significantly positive coefficients. Innovativeness, quality orientation and customer orientation involve a higher degree of multitasking at the individual job level. Altogether, the regressions confirm that the three business models are sensible indicators of multitasking.

\subsection{Robustness Checks}

We present a series of robustness checks increasing confidence in the basic pattern of results. Our data are stratified to establishment size classes, industries and regions. Building on Winship and Radbill (1994), we have controlled for the stratification characteristics and performed unweighted regressions. In Table B.5, we present weighted regressions adjusting for the stratification characteristics. This exercise confirms our key results.

So far we have used the log of screening as dependent variable. In Table B.6 we show the results of regressions with the level of applicant screening. Increased multitasking now emerges with a significantly positive coefficient. Most importantly, the regressions confirm a negative relationship between performance pay and applicant screening for establishments without 
increased multitasking and a positive relationship for establishments with increased multitasking.

Furthermore, we check if our results indeed reflect the influence of the intensity of performance pay and not simply the influence of performance pay incidence. The estimations shown in Table B.7 additionally include a dummy for performance pay incidence and an interaction of this dummy with the multitasking variable. While the two variables do not take significant coefficients, the role of performance pay intensity and its interaction with multitasking are confirmed.

One might wonder if the interaction between performance pay and multitasking masks an interaction with firm size or industry. Thus, we include additional interaction terms with firm size and industry. Table B.8 provides the results. Most of these interactions do not emerge with significant coefficients. Importantly, including the additional interactions does not change key results.

Finally, we run median regressions. Median regressions are more robust to outliers than OLS. As shown in Table B.9, median regressions confirm our key results.

\section{Conclusions}

Self-sorting models of performance pay predict that employers tying pay to individual performance attract high-ability workers. This suggests that employers need no intensive applicant screening if they make substantial use of performance pay. Our study shows that such negative relationship between performance pay and screening only holds for work arrangements with a lower degree of multitasking. If production is, however, characterized by a higher degree of multitasking, we find a positive relationship. This finding fits the hypothesis that, in case of increased multitasking, performance pay can entail problems of an adverse self-selection of workers. Only by combining performance pay with applicant screening employers can ensure 
that they attract the right employees to the more complex jobs.

On a broader scale, our study contributes to the debate over the best practices in human resource management. Proponents of the high-performance paradigm have searched for a bundle of best practices that is of virtually universal benefit to employers. Our findings support the view that a universal bundle of best practices does not exist. The relationship between performance pay and applicant screening crucially depends on the nature of production. If production is more complex, performance pay and applicant screening are complements. Yet, if production is less complex, they are substitutes.

We conclude with suggestions for future research. As discussed in Appendix A, our model is not ad hoc and makes testable predictions beyond the specific relationship we are primarily interested in. The model does not only make predictions on the relationship between performance pay and applicant screening under different types of work organization. It also makes predictions on the relationship between work organization and the intensity of performance pay. The model implies that employers are less likely to choose high-powered performance pay if production is characterized by multitasking. Future research could provide an in-depth analysis of the relationship between the nature of production and the intensity of performance pay.

Moreover, now that the relationship between performance pay and applicant screening has been studied, it would be interesting to examine their interaction effect on firm performance and the success of hiring decisions. Specifically, future research could examine if a possible interaction effect of performance pay and applicant screening depends on the nature of production. 
Table 1: Variable Definitions and Descriptive Statistics

\begin{tabular}{|c|c|c|c|}
\hline Variable & Description & Mean & Std. Dev \\
\hline $\begin{array}{l}\text { Time taken for the screening } \\
\text { of a non-managerial applicant }\end{array}$ & $\begin{array}{l}\text { Number of minutes taken on average for the screening of a } \\
\text { non-managerial applicant. }\end{array}$ & 166 & 163 \\
\hline $\begin{array}{l}\text { Time taken for the screening } \\
\text { of a managerial applicant }\end{array}$ & $\begin{array}{l}\text { Number of minutes taken on average for the screening of a } \\
\text { managerial applicant. }\end{array}$ & 330 & 280 \\
\hline $\begin{array}{l}\text { Individual-based performance } \\
\text { pay for non-managerial } \\
\text { employees }\end{array}$ & $\begin{array}{l}\text { Average percentage share of individual performance pay for } \\
\text { non-managerial employees in relation to their base pay. }\end{array}$ & 3.176 & 8.247 \\
\hline $\begin{array}{l}\text { Individual-based performance } \\
\text { pay for non-managerial } \\
\text { employees (dummy) }\end{array}$ & $\begin{array}{l}\text { Dummy equals } 1 \text { if the firm uses individual-based } \\
\text { performance pay for non-managerial employees. }\end{array}$ & 0.349 & 0.477 \\
\hline $\begin{array}{l}\text { Individual-based performance } \\
\text { pay for managerial employees }\end{array}$ & $\begin{array}{l}\text { Average percentage share of individual performance for } \\
\text { managerial employees in relation to their base pay. }\end{array}$ & 3.717 & 7.453 \\
\hline $\begin{array}{l}\text { Individual-based performance } \\
\text { pay for managerial employees } \\
\text { (dummy) }\end{array}$ & $\begin{array}{l}\text { Dummy equals } 1 \text { if the firm uses individual-based } \\
\text { performance pay for non-managerial employees. }\end{array}$ & 0.434 & 0.496 \\
\hline Increased multitasking & $\begin{array}{l}\text { Dummy equals } 1 \text { if the establishment's business model aims } \\
\text { at high quality, innovativeness, or customer-specific } \\
\text { solutions. }\end{array}$ & 0.936 & 0.244 \\
\hline High quality & $\begin{array}{l}\text { Dummy equals } 1 \text { if the establishment's business model aims } \\
\text { at high quality. }\end{array}$ & 0.434 & 0.496 \\
\hline Innovativeness & $\begin{array}{l}\text { Dummy equals } 1 \text { if the establishment's business model aims } \\
\text { at innovations. }\end{array}$ & 0.143 & 0.350 \\
\hline Customer-specific solutions & $\begin{array}{l}\text { Dummy equals } 1 \text { if the establishment's business model aims } \\
\text { at customer-specific solutions. }\end{array}$ & 0.359 & 0.480 \\
\hline $\begin{array}{l}\text { Group-based performance pay } \\
\text { for non-managerial employees }\end{array}$ & $\begin{array}{l}\text { Average percentage share of group-based performance pay } \\
\text { for non-managerial employees in relation to their base pay. }\end{array}$ & 1.112 & 3.622 \\
\hline $\begin{array}{l}\text { Group-based performance pay } \\
\text { for managerial employees }\end{array}$ & $\begin{array}{l}\text { Average percentage share of group-based performance pay } \\
\text { for managerial employees in relation to their base pay. }\end{array}$ & 1.955 & 5.279 \\
\hline $\begin{array}{l}\text { Profit sharing for non- } \\
\text { managerial employees }\end{array}$ & $\begin{array}{l}\text { Average percentage share of profit sharing pay for non- } \\
\text { managerial employees in relation to their base pay. }\end{array}$ & 1.547 & 4.293 \\
\hline $\begin{array}{l}\text { Profit sharing for managerial } \\
\text { employees }\end{array}$ & $\begin{array}{l}\text { Average percentage share of individual performance for } \\
\text { managerial employees in relation to their base pay. }\end{array}$ & 5.330 & 9.619 \\
\hline $\begin{array}{l}\text { Performance appraisals for } \\
\text { non-managerial employees }\end{array}$ & $\begin{array}{l}\text { Dummy equals } 1 \text { if the firm uses performance appraisals for } \\
\text { non-managerial employees and recommends a predetermined } \\
\text { distribution of ratings. }\end{array}$ & 0.069 & 0.254 \\
\hline $\begin{array}{l}\text { Performance appraisals for } \\
\text { managerial employees }\end{array}$ & $\begin{array}{l}\text { Dummy equals } 1 \text { if the firm uses performance appraisals for } \\
\text { managerial employees and recommends a predetermined } \\
\text { distribution of ratings. }\end{array}$ & 0.031 & 0.172 \\
\hline Number of employees & Number of employees in the establishment. & 394 & 1,792 \\
\hline Personnel management & $\begin{array}{l}\text { Dummy equals } 1 \text { if personnel management is embedded at } \\
\text { the top management level. }\end{array}$ & 0.446 & 0.497 \\
\hline Owner manager & Dummy equals 1 if the establishment is managed by its & 0.289 & 0.453 \\
\hline
\end{tabular}




\begin{tabular}{|c|c|c|c|}
\hline & owner. & & \\
\hline Limited company & $\begin{array}{l}\text { Dummy equals } 1 \text { if the establishment is a private limited } \\
\text { company. }\end{array}$ & 0.909 & 0.287 \\
\hline Foreign owner & $\begin{array}{l}\text { Dummy equals } 1 \text { if the establishment has a dominant } \\
\text { foreign owner. }\end{array}$ & 0.172 & 0.377 \\
\hline Collective bargaining & $\begin{array}{l}\text { Dummy equals } 1 \text { if the firm is covered by a collective } \\
\text { agreement. }\end{array}$ & 0.611 & 0.488 \\
\hline Works council & Dummy equals 1 if the establishment has a works council. & 0.643 & 0.479 \\
\hline Modern technology & $\begin{array}{l}\text { Dummy equals } 1 \text { if the establishment has a modern or very } \\
\text { modern production technology. }\end{array}$ & 0.716 & 0.451 \\
\hline Proportion of women & Share of female employees. & 0.317 & 0.240 \\
\hline $\begin{array}{l}\text { Proportion of university } \\
\text { graduates }\end{array}$ & Share of the workforce with university degrees. & 0.106 & 0.148 \\
\hline $\begin{array}{l}\text { Proportion of skilled } \\
\text { employees }\end{array}$ & $\begin{array}{l}\text { Share of the workforce with completed apprenticeship } \\
\text { training. }\end{array}$ & 0.638 & 0.248 \\
\hline Industry dummies & $\begin{array}{l}\text { Four dummies for metalworking and electronic industries, } \\
\text { other manufacturing industries, retail and transport, and } \\
\text { information and communication services are included. The } \\
\text { reference group is services for firms. }\end{array}$ & --- & --- \\
\hline Region dummies & $\begin{array}{l}\text { Three dummies for East Germany, Northern West Germany, } \\
\text { and Western West Germany are included. The reference } \\
\text { group consists of establishments located in Southern West } \\
\text { Germany. }\end{array}$ & --- & --- \\
\hline
\end{tabular}

$\mathrm{N}=1,036$. For the time taken for the screening of managerial employees and managerial performance pay, the number of observations is equal to 915 . 
Table 2: Determinants of the Time Taken for the Screening of a Non-Managerial Applicant

\begin{tabular}{|c|c|c|}
\hline & (1) & (2) \\
\hline Increased multitasking & $0.138(1.42)$ & $0.070(0.69)$ \\
\hline $\begin{array}{l}\text { Individual-based performance pay for non- } \\
\text { managerial employees }\end{array}$ & $0.005(1.91)^{*}$ & $-0.021(3.13)^{* * *}$ \\
\hline $\begin{array}{l}\text { Individual-based performance pay for non- } \\
\text { managerial employees } \mathrm{x} \text { increased multitasking }\end{array}$ & ---- & $0.027(3.84)^{* * *}$ \\
\hline $\begin{array}{l}\text { Group-based performance pay for non- } \\
\text { managerial employees }\end{array}$ & $0.009(1.49)$ & $0.009(1.39)$ \\
\hline Profit sharing for non-managerial employees & $0.010(1.90)^{*}$ & $0.011(1.98)^{* *}$ \\
\hline $\begin{array}{l}\text { Performance appraisals for non-managerial } \\
\text { employees }\end{array}$ & $0.222(2.29)^{* *}$ & $0.217(2.24)^{* *}$ \\
\hline Number of employees / 1,000 & $0.018(1.46)$ & $0.018(1.45)$ \\
\hline Personnel management & $-0.043(0.83)$ & $-0.041(0.78)$ \\
\hline Owner manager & $-0.108(1.63)$ & $-0.110(1.65)$ \\
\hline Limited company & $0.012(0.13)$ & $0.015(0.16)$ \\
\hline Foreign owner & $0.036(0.56)$ & $0.034(0.53)$ \\
\hline Collective bargaining & $0.062(1.01)$ & $0.065(0.53)$ \\
\hline Works council & $0.150(2.30)^{* *}$ & $0.145(2.24)^{* *}$ \\
\hline Modern technology & $0.063(1.12)$ & $0.062(1.11)$ \\
\hline Proportion of women & $0.048(0.35)$ & $0.049(0.36)$ \\
\hline Proportion of university graduates & $0.387(2.13)^{* *}$ & $0.381(2.10)^{* *}$ \\
\hline Proportion of skilled workers & $0.026(0.21)$ & $0.028(0.23)$ \\
\hline Constant & $4.545(22.70)^{* * *}$ & $4.461(20.34)^{* * *}$ \\
\hline Industry and region dummies & Included & Included \\
\hline $\mathrm{N}$ & 1,036 & 1,036 \\
\hline R squared & 0.080 & 0.083 \\
\hline
\end{tabular}

Dependent variable: Log of number of minutes taken on average for the screening of a non-managerial applicant. Method: OLS. The table shows the estimated coefficients. $t$-statistics in parentheses are based on robust standard errors. $* * *$ Statistically significant at the $1 \%$ level; $* *$ at the $5 \%$ level; $*$ at the $10 \%$ level. 
Table 3: Determinants of the Time Taken for the Screening of a Managerial Applicant

\begin{tabular}{|l|l|l|}
\hline & \multicolumn{1}{|c|}{$(1)$} & \multicolumn{1}{|c|}{$(2)$} \\
\hline Increased multitasking & $0.195(1.97)^{* *}$ & $0.069(0.68)$ \\
\hline $\begin{array}{l}\text { Individual-based performance pay for managerial } \\
\text { employees }\end{array}$ & $0.004(1.40)$ & $-0.025(4.08)^{* * *}$ \\
\hline $\begin{array}{l}\text { Individual-based performance pay for managerial } \\
\text { employees x increased multitasking }\end{array}$ & \multicolumn{1}{|c|}{---} & $0.032(4.70)^{* * *}$ \\
\hline $\begin{array}{l}\text { Group-based performance pay for managerial } \\
\text { employees }\end{array}$ & $0.006(1.41)$ & $0.005(1.26)$ \\
\hline Profit sharing for managerial employees & $0.005(1.57)$ & $0.005(1.58)$ \\
\hline Performance appraisals for managerial employees & $0.252(1.56)$ & $0.252(1.57)$ \\
\hline Number of employees / 1,000 & $0.022(2.17)^{* *}$ & $0.022(2.19)^{* *}$ \\
\hline Personnel management & $0.018(0.32)$ & $0.026(0.48)$ \\
\hline Owner manager & $-0.093(1.40)$ & $-0.095(1.43)$ \\
\hline Limited company & $0.030(0.31)$ & $0.022(0.23)$ \\
\hline Foreign owner & $0.010(0.15)$ & $0.010(0.14)$ \\
\hline Collective bargaining & $0.113(1.85)^{*}$ & $0.114(1.87)^{*}$ \\
\hline Works council & $0.126(1.84)^{*}$ & $0.123(1.81)^{*}$ \\
\hline Modern technology & $0.011(0.19)$ & $0.011(0.19)$ \\
\hline Proportion of women & $0.077(0.50)$ & $0.057(0.37)$ \\
\hline Proportion of university graduates & $0.070(0.39)$ & $0.069(0.38)$ \\
\hline Proportion of skilled workers & $-0.047(0.35)$ & $-0.040(0.30)$ \\
\hline Constant & $5.281(25.26)^{* * *}$ & $5.407(25.75)^{* * *}$ \\
\hline Industry and region dummies & Included & Included \\
\hline N & 915 & 915 \\
\hline R squared & 0.066 & 0.072 \\
\hline Depor & & \\
\hline
\end{tabular}

Dependent variable: Log of number of minutes taken on average for the screening of a managerial applicant. Method: OLS. The table shows the estimated coefficients. $t$-statistics in parentheses are based on robust standard errors. $* * *$ Statistically significant at the $1 \%$ level; $* *$ at the $5 \%$ level; $*$ at the $10 \%$ level. 
Table 4: Interactions with Group-Based Performance Pay and Profit Sharing

\begin{tabular}{|c|c|c|}
\hline & $\begin{array}{l}\text { Dependent variable: } \\
\text { Log of number of } \\
\text { minutes taken on } \\
\text { average for the } \\
\text { screening of non- } \\
\text { managerial applicants }\end{array}$ & $\begin{array}{l}\text { Dependent variable: } \\
\text { Log of number of } \\
\text { minutes taken on } \\
\text { average for the } \\
\text { screening of } \\
\text { managerial applicants }\end{array}$ \\
\hline & $(1)$ & $(2)$ \\
\hline Increased multitasking & $0.021(0.17)$ & $0.075(0.60)$ \\
\hline Individual-based performance pay & $-0.022(3.92) * * *$ & $-0.027(3.25)^{* * *}$ \\
\hline $\begin{array}{l}\text { Individual performance pay } \mathrm{x} \text { increased } \\
\text { multitasking }\end{array}$ & $0.029(4.81)^{* * *}$ & $0.036(3.94)^{* * *}$ \\
\hline Group-based performance pay & $-0.002(0.03)$ & $0.033(0.97)$ \\
\hline $\begin{array}{l}\text { Group-based performance pay } \mathrm{x} \text { increased } \\
\text { multitasking }\end{array}$ & $0.016(0.24)$ & $-0.029(0.83)$ \\
\hline Profit sharing & $-0.066(0.92)$ & $-0.024(1.14)$ \\
\hline Profit sharing $\mathrm{x}$ increased multitasking & $0.079(1.10)$ & $0.032(1.51)$ \\
\hline $\begin{array}{l}\text { Individual-based performance pay } \mathrm{x} \text { group- } \\
\text { based performance pay }\end{array}$ & $-0.011(0.73)$ & $0.004(0.32)$ \\
\hline $\begin{array}{l}\text { Individual-based performance pay } \mathrm{x} \text { group- } \\
\text { based performance pay } \mathrm{x} \text { increased } \\
\text { multitasking }\end{array}$ & $0.011(0.71)$ & $0.003(0.30)$ \\
\hline $\begin{array}{l}\text { Individual-based performance pay } \mathrm{x} \text { profit } \\
\text { sharing }\end{array}$ & $0.006(1.33)$ & $0.001(1.03)$ \\
\hline $\begin{array}{l}\text { Individual-based performance pay } \mathrm{x} \text { profit } \\
\text { sharing } \mathrm{x} \text { increased multitasking }\end{array}$ & $-0.006(1.36)$ & $-0.001(1.28)$ \\
\hline $\begin{array}{l}\text { Group-based performance pay x profit } \\
\text { sharing }\end{array}$ & $0.038(0.91)$ & $0.018(1.64)$ \\
\hline $\begin{array}{l}\text { Group-based performance pay x profit } \\
\text { sharing x increased multitasking }\end{array}$ & $-0.038(0.92)$ & $-0.018(1.68)^{*}$ \\
\hline $\begin{array}{l}\text { Individual-based performance pay } \mathrm{x} \text { group- } \\
\text { based performance pay } \mathrm{x} \text { profit sharing }\end{array}$ & $-0.0001(0.18)$ & $-0.0001(0.75)$ \\
\hline $\mathrm{N}$ & 1036 & 915 \\
\hline $\mathrm{R}$ squared & 0.085 & 0.079 \\
\hline
\end{tabular}

In regression (1), the variables for individual-based performance pay, group-based performance pay and profit sharing refer to non-managerial employees. In regression (2), these variables refer to managerial employees. Method: OLS. The table shows the estimated coefficients. $t$-statistics in parentheses are based on robust standard errors. *** Statistically significant at the $1 \%$ level; $*$ at the $10 \%$ level. Note that all of the other control variables are included but are suppressed to save space. 
Table 5: Interactions with Performance Appraisals

\begin{tabular}{|l|l|l|}
\hline & $\begin{array}{c}\text { Dependent variable: } \\
\text { Log of number of } \\
\text { minutes taken on } \\
\text { average for the } \\
\text { screening of non- } \\
\text { managerial applicants }\end{array}$ & $\begin{array}{c}\text { Dependent variable: } \\
\text { Log of number of } \\
\text { minutes taken on } \\
\text { average for the } \\
\text { screening of } \\
\text { managerial applicants }\end{array}$ \\
\hline Increased multitasking & $(1)$ & $(2)$ \\
\hline Individual-based performance pay & $0.092(0.88)$ & $0.069(0.66)$ \\
\hline $\begin{array}{l}\text { Individual-based performance pay } \mathrm{x} \\
\text { increased multitasking }\end{array}$ & $-0.019(2.85)^{* * * *}$ & $-0.025(4.00)^{* * *}$ \\
\hline Performance appraisals & $0.027(3.72)^{* * *}$ & $0.031(4.56)^{* * *}$ \\
\hline $\begin{array}{l}\text { Performance appraisals x increased } \\
\text { multitasking }\end{array}$ & $0.820(4.97)^{* * *}$ & $0.305(2.32)^{* *}$ \\
\hline $\begin{array}{l}\text { Individual performance pay x performance } \\
\text { appraisals }\end{array}$ & $-0.590(3.06)^{* * * *}$ & $0.222(0.84)$ \\
\hline $\begin{array}{l}\text { Individual-based performance pay } \mathrm{x} \\
\text { performance appraisals x increased } \\
\text { multitasking }\end{array}$ & $0.376(2.81)^{* * *}$ & $0.054(1.42)$ \\
\hline $\mathrm{N}$ & & $-0.016(0.85)$ \\
\hline $\mathrm{R}$ squared & 1,036 & 915 \\
\hline In & 0.085 & 0.074 \\
\hline
\end{tabular}

In regression (1), the variables for individual-based performance pay and performance appraisals refer to non-managerial employees. In regression (2), these variables refer to managerial employees. Method: OLS. The table shows the estimated coefficients. $t$-statistics in parentheses are based on robust standard errors. ${ }^{* *}$ Statistically significant at the $1 \%$ level; $* *$ at the $5 \%$ level. Note that all of the other control variables are included but are suppressed to save space. 
Table 6: Determinants of Task Variety at the Individual Job Level

\begin{tabular}{|c|c|c|c|c|c|c|}
\hline & (1) & $(2)$ & (3) & (4) & (5) & (6) \\
\hline Increased multitasking & $\begin{array}{l}0.358 \\
(2.80)^{* * *}\end{array}$ & $\begin{array}{l}0.338 \\
(2.50)^{* *}\end{array}$ & $\begin{array}{l}0.328 \\
(2.25)^{* *}\end{array}$ & ---- & ---- & ---- \\
\hline High quality & --- & --- & --- & $\begin{array}{l}0.359 \\
(2.70)^{* * *}\end{array}$ & $\begin{array}{l}0.350 \\
(2.51)^{* *}\end{array}$ & $\begin{array}{l}0.335 \\
(2.25)^{* *}\end{array}$ \\
\hline Customer-specific solutions & ---- & ---- & ---- & $\begin{array}{l}0.358 \\
(2.68)^{* * *}\end{array}$ & $\begin{array}{l}0.329 \\
(2.33)^{* *}\end{array}$ & $\begin{array}{l}0.315 \\
(2.08) * *\end{array}$ \\
\hline Innovativeness & ---- & ---- & ---- & $\begin{array}{l}0.356 \\
(2.59)^{* * * *}\end{array}$ & $\begin{array}{l}0.332 \\
(2.31)^{* * * *}\end{array}$ & $\begin{array}{l}0.334 \\
(2.18)^{* *}\end{array}$ \\
\hline Man & $\begin{array}{ll}--- \\
\end{array}$ & $\begin{array}{l}-0.067 \\
(1.04)\end{array}$ & $\begin{array}{l}-0.053 \\
(0.76)\end{array}$ & ---- & $\begin{array}{l}-0.066 \\
(1.03)\end{array}$ & $\begin{array}{l}-0.052 \\
(0.75)\end{array}$ \\
\hline Age & $\begin{array}{ll}--- \\
\end{array}$ & $\begin{array}{l}0.008 \\
(3.03)^{* * *}\end{array}$ & $\begin{array}{l}0.009 \\
(3.17)^{* * *}\end{array}$ & $\begin{array}{ll}--- \\
\end{array}$ & $\begin{array}{l}0.008 \\
(3.03)^{* * *}\end{array}$ & $\begin{array}{l}0.009 \\
(3.17)^{* * *}\end{array}$ \\
\hline University graduate & ---- & $\begin{array}{l}0.209 \\
(3.54)^{* * *}\end{array}$ & $\begin{array}{l}0.207 \\
(3.41)^{* * *}\end{array}$ & ---- & $\begin{array}{l}0.210 \\
(3.55)^{* * *}\end{array}$ & $\begin{array}{l}0.207 \\
(3.41)^{* * * *}\end{array}$ \\
\hline German citizen & $\begin{array}{ll}--- \\
\end{array}$ & $\begin{array}{l}0.062 \\
(0.32)\end{array}$ & $\begin{array}{l}0.085 \\
(0.43)\end{array}$ & $\begin{array}{ll}--- \\
\end{array}$ & $\begin{array}{l}0.061 \\
(0.31)\end{array}$ & $\begin{array}{l}0.084 \\
(0.42)\end{array}$ \\
\hline Blue-collar worker & ---- & $\begin{array}{l}-0.164 \\
(2.73)^{* * *}\end{array}$ & $\begin{array}{l}-0.191 \\
(2.88)^{* * *}\end{array}$ & ---- & $\begin{array}{l}-0.164 \\
(2.73)^{* * *}\end{array}$ & $\begin{array}{l}-0.191 \\
(2.88)^{* * *}\end{array}$ \\
\hline Working hours & $\begin{array}{ll}--- \\
\end{array}$ & $\begin{array}{l}0.027 \\
(4.81)^{* * *}\end{array}$ & $\begin{array}{l}0.029 \\
(4.99) * * *\end{array}$ & $\begin{array}{ll}--- \\
\end{array}$ & $\begin{array}{l}0.027 \\
(4.81)^{* * *}\end{array}$ & $\begin{array}{l}0.029 \\
(4.99) * * *\end{array}$ \\
\hline $100-249$ employees & $\begin{array}{ll}--- \\
\end{array}$ & ---- & $\begin{array}{l}-0.085 \\
(0.97)\end{array}$ & $\begin{array}{ll}--- \\
\end{array}$ & --- & $\begin{array}{l}-0.088 \\
(1.00)\end{array}$ \\
\hline 250 - 499 employees & $\begin{array}{l}--- \\
\end{array}$ & $\begin{array}{l}---- \\
\end{array}$ & $\begin{array}{l}0.092 \\
(0.97)\end{array}$ & ---- & ---- & $\begin{array}{l}0.091 \\
(0.96)\end{array}$ \\
\hline 500 und more employees & $\begin{array}{ll}--- \\
\end{array}$ & $\begin{array}{ll}--- \\
\end{array}$ & $\begin{array}{l}-0.029 \\
(0.31)\end{array}$ & $\begin{array}{ll}--- \\
\end{array}$ & $\begin{array}{ll}--- \\
\end{array}$ & $\begin{array}{l}-0.033 \\
(0.34)\end{array}$ \\
\hline Personnel management & $\begin{array}{ll}--- \\
\end{array}$ & $\begin{array}{ll}--- \\
\end{array}$ & $\begin{array}{l}0.072 \\
(1.26)\end{array}$ & ---- & $\begin{array}{ll}--- \\
\end{array}$ & $\begin{array}{l}0.072 \\
(1.26)\end{array}$ \\
\hline Owner manager & ---- & ---- & $\begin{array}{l}-0.012 \\
(0.15)\end{array}$ & ---- & ---- & $\begin{array}{l}-0.014 \\
(0.18)\end{array}$ \\
\hline Limited company & $\begin{array}{ll}--- \\
\end{array}$ & $\begin{array}{ll}--- \\
\end{array}$ & $\begin{array}{l}0.018 \\
(0.18)\end{array}$ & $\begin{array}{ll}--- \\
\end{array}$ & $\begin{array}{ll}--- \\
\end{array}$ & $\begin{array}{l}0.020 \\
(0.20)\end{array}$ \\
\hline Foreign owner & ---- & ---- & $\begin{array}{l}-0.024 \\
(0.33)\end{array}$ & ---- & ---- & $\begin{array}{l}-0.024 \\
(0.34)\end{array}$ \\
\hline Collective bargaining & $\begin{array}{ll}--- \\
\end{array}$ & $\begin{array}{ll}--- \\
\end{array}$ & $\begin{array}{l}0.014 \\
(0.21)\end{array}$ & $\begin{array}{ll}--- \\
\end{array}$ & $\begin{array}{ll}--- \\
\end{array}$ & $\begin{array}{l}0.014 \\
(0.21)\end{array}$ \\
\hline Works council & $\begin{array}{ll}--- \\
\end{array}$ & $\begin{array}{ll}--- \\
\end{array}$ & $\begin{array}{l}-0.178 \\
(2.09)^{* *}\end{array}$ & $\begin{array}{ll}--- \\
\end{array}$ & ---- & $\begin{array}{l}-0.180 \\
(2.11)^{* *}\end{array}$ \\
\hline Modern technology & $\begin{array}{c}--- \\
--1\end{array}$ & ---- & $\begin{array}{l}-0.015 \\
(0.21)\end{array}$ & ---- & ---- & $\begin{array}{l}-0.016 \\
(0.23)\end{array}$ \\
\hline Share of female employees & $\begin{array}{ll}--- \\
\end{array}$ & $\begin{array}{ll}--- \\
\end{array}$ & $\begin{array}{l}0.412 \\
(2.52) * *\end{array}$ & ---- & $\begin{array}{ll}--- \\
\end{array}$ & $\begin{array}{l}0.411 \\
(2.52)^{* *}\end{array}$ \\
\hline Share of university graduates & $\begin{array}{c}--- \\
\end{array}$ & $\begin{array}{c}--- \\
\end{array}$ & $\begin{array}{l}-0.237 \\
(1.09)\end{array}$ & $\begin{array}{c}--- \\
\end{array}$ & $\begin{array}{c}--- \\
\end{array}$ & $\begin{array}{l}-0.233 \\
(1.07)\end{array}$ \\
\hline Share of skilled workers & $\begin{array}{c}--- \\
-1\end{array}$ & $\begin{array}{c}--- \\
-1\end{array}$ & $\begin{array}{l}0.149 \\
(1.15)\end{array}$ & $\begin{array}{c}--- \\
\end{array}$ & $\begin{array}{ll}--- \\
\end{array}$ & $\begin{array}{l}0.148 \\
(1.15)\end{array}$ \\
\hline Industry and Region Controls & No & No & Yes & No & No & Yes \\
\hline $\log \mathrm{L}$ & -6076 & -6036 & -6013 & -6076 & -6036 & -6013 \\
\hline Number of employees & 5409 & 5409 & 5409 & 5409 & 5409 & 5409 \\
\hline Number of establishments & 788 & 788 & 788 & 788 & 788 & 788 \\
\hline
\end{tabular}

Dependent variable: Task variety. Method: Ordered Probit. The table shows the estimated coefficients. $z$-statistics in parentheses are based on standard errors clustered at the establishment level. *** Statistically significant at the $1 \%$ level; ** at the $5 \%$ level. 


\section{References}

Acemoglu, Daron, Michael Kremer and Atif Mian. 2008. "Incentives in Markets, Firms, and Governments," Journal of Law, Economics and Organization 24: 273 - 306.

Artz, Benjamin and John S. Heywood. 2015. "Performance Pay and Workplace Injury: Panel Evidence," Economica 82: 1241 - 1260.

Askildsen, Jan Erik, Uwe Jirjahn and Stephen C. Smith. 2006. "Works Councils and Environmental Investment: Theory and Evidence from German Panel Data," Journal of Economic Behavior and Organization 60: $346-372$.

Autor, David and David Scarborough. 2008. "Does Job Testing Harm Minority Workers? Evidence from Retail Establishments," Quarterly Journal of Economics 123: 219 - 277.

Baker, George. 1992. "Incentive Contracts and Performance Measurement," Journal of Political Economy 100: 598 - 613.

Baker, George. 2002. "Distortion and Risk in Optimal Incentive Contracts," Journal of Human Resources 37: $728-751$.

Baker, George, Michael Jensen and Kevin Murphy. 1988. "Compensation and Incentives: Practice vs. Theory," Journal of Finance 18: 593 - 616.

Bandiera, Oriana, Luigi Guiso, Andrea Prat and Raffaella Sadun. 2015. "Matching Firms, Managers, and Incentives," Journal of Labor Economics 33: 623 - 681.

Barnes, C., J. Hollenbeck, D. Jundt, D. DeRue and S. Harmon. 2011. "Mixing Individual Incentives and Group Incentives: Best of Both Worlds or Social Dilemma?" Journal of Management 37: 1611 1635 .

Bartling, Björn, Ernst Fehr and Klaus Schmidt. 2012. "Screening, Competition, and Job Design: Economic Origins of Good Jobs," Amercian Economic Review 102: 834 - 864.

Benabou, Roland and Jean Tirole. 2016. "Bonus Culture: Competitive Pay, Screening, and Multitasking," Journal of Political Economy 124: 305 - 370.

Bender, Keith A., Colin P. Green and John S. Heywood. 2012. "Piece Rates and Workplace Injury: Does Survey Evidence Support Adam Smith?” Journal of Population Economics 25: 569 - 90.

Caroli, Eve and John van Reenen. 2001. "Skill-Biased Organizational Change? Evidence from a Panel of British and French Establishments," Quarterly Journal of Economics 116: 1449 - 1492.

Conte, Jeffrey and Jeremy Ginftoft. 2005. "Polychronicity, Big Five Personality Dimensions, and Sales Performance," Human Performance 18: 427 - 444.

Cornelissen, Thomas, John S. Heywood and Uwe Jirjahn. 2011. "Performance Pay, Risk Attitudes and Job Satisfaction," Labour Economics 18: 229 - 239.

Cornelissen, Thomas, John S. Heywood and Uwe Jirjahn. 2014. "Reciprocity and Profit Sharing: Is There an Inverse U-Shaped Relationship?” Journal of Labor Research 35: 205 - 225. 
Curme, Michael and Noah Stefanec. 2007. "Worker Quality and Labor Market Sorting," Economics Letters 96: $202-208$.

DeVaro, Jed. 2005. "Employer Recruitment Strategies and the Labor Market Outcomes of New Hires," Economic Inquiry 43: 263 - 282.

Dohmen, Thomas and Armin Falk. 2011. "Performance Pay and Multidimensional Sorting: Productivity, Preferences, and Gender," American Economic Review 101: 556 - 590.

Drago, Robert and Gerald Garvey. 1998. "Incentives for Helping on the Job: Theory and Evidence," Journal of Labor Economics 16: 1 - 25.

Drago, Robert and John S. Heywood. 1995. "The Choice of Payment Schemes: Australian Evidence," Industrial Relations 34: 507 - 531.

Fischer, Gabriele, Florian Janik, Dana Mueller and Alexandra Schmucker. 2009. "The IAB Establishment Panel - Things Users Should Know,” Journal of Applied Social Science Studies 129: 133 - 48.

Freeman, Richard and Morris Kleiner. 2005. "The Last American Shoe Manufacturers: Decreasing Productivity and Increasing Profits in the Shift from Piece Rates to Continuous Flow Production," Industrial Relations 44: 307 - 330.

Griffith, Rachel and Andrew Neely. 2009. "Performance Pay and Managerial Experience in Multitask Teams: Evidence from within a Firm," Journal of Labor Economics 27: 49 - 82.

Hellmann, Thomas and Veikko Thiele. 2011. "Incentives and Innovation: A Multitasking Approach," American Economic Journal: Microeconomics 3: 78 - 128.

Heywood, John S. and Uwe Jirjahn. 2009. "Profit Sharing and Firm Size: The Role of Team Production," Journal of Economic Behavior and Organization 71: 246 - 258.

Heywood, John S., Uwe Jirjahn and Cornelia Struewing. 2017. "Locus of Control and Performance Appraisal," Journal of Economic Behavior and Organization 142: 205 - 225.

Heywood, John S., Uwe Jirjahn and Georgi Tsertsvadze. 2010. "Hiring Older Workers and Employing Older Workers: German Evidence," Journal of Population Economics 23: 595 - 615.

Holmstrom, Bengt and Paul Milgrom. 1991. "Multitask Principal-Agent Analyses: Incentive Contracts, Asset Ownership and Job Design," Journal of Law, Economics and Organization 7: 24 - 52.

Hough, Leaetta and Frederick Oswald. 2008. "Personality Testing and Industrial-Organizational Psychology: Reflections, Progress, and Prospects," Industrial and Organizational Psychology 1: $272-290$.

Huang, Fali and Peter Capelli. 2010. "Applicant Screening and Performance-Related Outcomes," American Economic Review 100: 214 - 218.

Huebler, Olaf and Uwe Jirjahn. 2003. "Works Councils and Collective Bargaining in Germany - The Impact on Productivity and Wages" Scottish Journal of Political Economy 50: 1 - 21.

Judge, Timothy, Ryan Klinger, Lauren Simon and Irene Wen Fen Yang. 2008. "The Contributions of Personality to Organizational Behavior and Psychology: Findings, Criticisms, and Future Research 
Directions," Social and Personality Psychology Compass 2/5: 1982 - 2000.

Ichniowski, Casey, Kathryn Shaw and Giovanna Prennushi. 1997. "The Effects of Human Resource Management Practices on Productivity: A Study of Steel Finishing Lines," American Economic Review 87: $291-313$.

Jirjahn, Uwe. 2000. "Incentives for Multitasking: Fixed Wages or Profit Sharing?" Economic Analysis 3: $137-148$.

Jirjahn, Uwe. 2006. “A Note on Efficiency Wage Theory and Principal-Agent Theory," Bulletin of Economic Research 58: 235 - 252.

Jirjahn, Uwe. 2018. "The Adoption and Termination of Profit Sharing for Employees: Does Management's Attitude Play a Role?" Applied Economics 50: 108 - 127.

Jirjahn, Uwe and Kornelius Kraft. 2011. "Do Spillovers Stimulate Incremental or Drastic Product Innovations? Evidence from German Establishment Data," Oxford Bulletin of Economics and Statistics 73: $509-538$.

Jirjahn, Uwe and Erik Poutsma. 2013. "The Use of Performance Appraisal Systems: Evidence from Dutch Establishment Data," Industrial Relations 52: 801 - 828.

Kampkoetter, Patrick, Jens Mohrenweiser, Dirk Sliwka, Susanne Steffes and Stefanie Wolter. 2016. "Measuring the Use of Human Resources Practices and Employee Attitudes: The Linked Personnel Panel," Evidence-Based Human Resource Management 4: 94 - 115.

Kampkoetter, Patrick and Dirk Sliwka. 2016. "The Complementary Use of Experiments and Field Data to Evaluate Management Practices: The Case of Subjective Performance Evaluations," Journal of Institutional and Theoretical Economics 172: 364 - 389.

Kandel, Eugene and Edward Lazear. 1992."Peer Pressure and Partnerships," Journal of Political Economy 100: $801-17$.

Kosfeld Michael and Ferdinand von Siemens. 2011. "Competition, Cooperation, and Corporate Culture," RAND Journal of Economics 42: 23 - 43.

Koenig, Cornelius, Lourdes Oberacher and Martin Kleinmann. 2010. "Personal and Situational Determinants of Multitasking at Work," Journal of Personnel Psychology 9: 99 - 103.

Laffont, Jean and David Martimort. 2002. The Theory of Incentives: The Principal-Agent Model. Princeton University Press, Princeton.

Laursen, K. and N. Foss. 2003. "New Human Resource Management Practices, Complementarities and the Impact on Innovation Performance," Cambridge Journal of Economics 27: 243 - 263.

Lazear, Edward P. 1986. "Salaries and Piece Rates,” Journal of Business 59: 405 - 431.

Lazear, Edward P. 2000. "Performance Pay and Productivity," American Economic Review 90: 1346 1361.

Lindbeck, Assar and Dennis Snower. 2000. "Multitask Learning and the Reorganization of Work: From Tayloristic to Holistic Production," Journal of Labor Economics 18: 353 - 376. 
Macho-Stadler, Ines and David Perez-Castrillo. 2017. "Moral Hazard: Base Models and Two Extensions," in L.C. Corcon and M.A. Marini, eds., Handbook of Game Theory and Industrial Organization, Edward Elgar, Forthcoming.

Milgrom, Paul and John Roberts. 1988. "An Economic Approach to Influence Activities in Organizations," American Journal of Sociology 94: S154 - S179.

Moen, Espen and Asa Rosen. 2005. "Performance Pay and Adverse Selection," Scandinavian Journal of Economics 107: 279 - 298.

Morita, Hodaka. 2005. "Multi-Skilling, Delegation and Continuous Process Improvement: A Comparative Analysis of US-Japanese Work Organizations," Economica 72: 69 - 93.

Oyer, Paul and Scott Schaefer. 2011. "Personnel Economics: Hiring and Incentives," in Handbook of Labor Economics Vol. 4B, edited by David Card and Orley Ashenfelter, Elsevier, Amsterdam: $1769-1823$.

Pendleton, Andrew. 2006. "Incentives, Monitoring, and Employee Stock Ownership Plans: New Evidence and Interpretations," Industrial Relations 45: 753 - 777.

Pendleton, Andrew and Andrew Robinson. 2015. "The Productivity Effects of Multiple Pay Incentives," Economic and Industrial Democracy, Forthcoming.

Penney, L., E. David and L. Witt. 2011. "A Review of Personality and Performance: Identifying Boundaries, Contingencies, and Future Research Directions," Human Resource Management Review 21: $297-310$.

Prendergast, Canice. 1999. "The Provision of Incentives in Firms," Journal of Economic Literature 37: 7 -63 .

Prendergast, Canice and Robert Topel. 1993. "Discretion and Bias in Performance Evaluation," European Economic Review 37: 355 - 365.

Rothstein, Mitchell and Richard Goffin. 2006. "The Use of Personality Measures in Personnel Selection: What Does Current Research Support?” Human Resource Management Review 16: 155 - 180.

Sappington, David. 1983. "Limited Liability Contracts between Principal and Agent," Journal of Economic Theory 29: 1-21.

Tett, Robert and Neil Christiansen. 2007. "Personality Tests at the Crossroads: A Response to Morgeson, Campion, Dipboye, Hollenbeck, Murphy, and Schmitt (2007)," Personnel Psychology 60: 967 993.

Tirole, J. 2001. “Corporate Governance,” Econometrica 69: 1 - 35.

Winship, C. and L. Radbil. 1994. "Sampling Weights and Regression Analysis," Sociological Methods and Research 23: $230-257$.

Zwick, T. 2011. "Seniority Wages and Establishment Characteristics," Labour Economics 18: 853 - 861. 


\section{Endnotes}

${ }^{1}$ We use the term 'ability' in a broad sense. It refers to all worker characteristics that are relevant for a worker's productivity. Depending on the respective job, ability can involve professional qualification, cognitive and non-cognitive skills, manual skills, or physical and mental fitness.

${ }^{2}$ The other half was attributable to higher effort.

${ }^{3}$ By distinguishing between low-powered and high-powered performance pay, our model captures the idea that not simply the presence, but rather the intensity of performance pay plays a role in self-sorting. Our empirical analysis uses a continuous variable for the intensity of performance pay.

${ }^{4}$ In reality even simple tasks may involve some degree of multitasking. The assumption of a singledimensional task can be seen as a theoretical simplification. It is a metaphor for a low degree of multitasking. In the extension of our model, we contrast the single-dimensional task with a twodimensional task. The two-dimensional task can be seen as a metaphor for a high degree of multitasking. ${ }^{5}$ While models on multitasking usually examine moral hazard, some recent theoretical advances consider multitasking also within models of adverse selection. Benabou and Tirole (2016) and Moen and Rosen (2005) present models showing that performance pay attracts high-ability workers only in the measurable performance dimension and distorts the allocation of effort across tasks. Increased competition for highability workers leads firm to rely heavily on performance pay and results in an increased distortion of the allocation of effort. In a model by Kosfeld and von Siemens (2011), workers differ in their cooperativeness with cooperation being non-verifiable. The model implies a separating equilibrium in which less cooperative workers sort themselves in firms with performance pay and cooperative workers sort themselves in firms with low-powered incentives.

${ }^{6}$ In Lazear's (1986) model workers in the performance pay sector obtain the complete rent of production because perfect competition among employers drives expected profits to zero. In our model, the limited liability constraint implies that workers receive a rent. The restrictive assumption of perfect competition is not required.

${ }^{7}$ Of course, this only means a reduced screening intensity and does not necessarily imply that the need for 
screening is completely eliminated. In our theoretical model we assume just for the sake of simplicity that the employer's screening decision is a dichotomous yes-or-no decision.

${ }^{8}$ Assumptions (2a) to (2c) can be illustrated by the following simple function: $\rho(e, \theta)=(\theta-\underline{\theta}) e+$ $(\theta-\underline{\theta})+\tau e$. In order to ensure that the probability is in the range between zero and one, let us assume that $0<\tau<1,0<(\bar{\theta}-\underline{\theta})<1$, and $0<2(\bar{\theta}-\underline{\theta})+\tau<1$. This function has two crucial features. On the one hand, it implies that effort and ability are complementary. On the other hand, it shows that effort yields a positive success probability even when coupled with low ability and, vice versa, high ability yields a positive success probability even without effort. We can interpret the effort in our model as extra effort in addition to some standard effort. For a high-ability worker, this standard effort is sufficient to generate a positive success probability. For a low-ability worker, the standard effort is not sufficient so that extra effort is required to generate a positive success probability. The simple function implies the following probabilities of success: $\rho(0, \underline{\theta})=0, \rho(1, \underline{\theta})=\tau, \rho(0, \bar{\theta})=(\bar{\theta}-\underline{\theta})$, and $\rho(1, \bar{\theta})=$ $2(\bar{\theta}-\underline{\theta})+\tau$. The probabilities have properties (2a) to (2c).

${ }^{9}$ For example, let $\gamma=\delta(\theta-\underline{\theta})$ represent the quality of output where $\delta>0$. The value of the agent's output for the principal is then given by $S(\theta, Q)=\delta(\theta-\underline{\theta}) Q$. This implies $S(\bar{\theta}, Q)=\delta(\bar{\theta}-\underline{\theta}) Q$ and $S(\underline{\theta}, Q)=0$.

${ }^{10}$ The insight that the existence of a rent depends on the agent's reservation utility often remains hidden in models using a limited liability approach as the agent's reservation utility is usually normalized to zero (e.g., Tirole 2001). Thus, the agent automatically receives a rent in those models.

${ }^{11}$ The rent cannot be reduced, as the agent is protected by limited liability. If the agent were not protected by limited liability, the principal could specify a performance payment $W=\alpha^{*} Q+\beta$ with a negative fixed component $\beta=-\left(E U^{*}-\bar{U}\right)$. That payment scheme would yield an expected utility equal to the reservation utility: $E U=\rho(1, \bar{\theta}) \alpha^{*} q+\beta-c=\bar{U}$. This would imply a negative wage if the project fails: 
$W=-\left(E U^{*}-\bar{U}\right)$ if $q=0$. Such negative wage may be interpreted as a performance bond (Jirjahn 2006, Sappington 1983). However, a negative wage is not feasible with the limited liability constraint $W \geq 0$. ${ }^{12} \alpha^{* *}<\alpha^{*} \Leftrightarrow \bar{U} / \rho(0, \bar{\theta})<c /(\rho(1, \bar{\theta})-\rho(0, \bar{\theta})) \Leftrightarrow \bar{U}<E U^{*}$.

${ }^{13}$ Modeling effort in the second performance dimension would not yield additional insights. Output in the second performance dimension is not verifiable so performance pay cannot be based on that dimension. As a consequence, the agent has no incentive to exert additional effort in the second performance dimension.

${ }^{14}$ It is a standard assumption in adverse selection models that agents tell the truth when lying yields no advantage (e.g., Laffont and Martimort 2002).

${ }^{15}$ This is similar to Holmstrom and Milgrom's (1991) model of multitasking and moral hazard. In that model the agent exerts voluntarily some minimum level of effort and follows the principal's instructions in allocating the effort across tasks.

${ }^{16}$ Of course, applicants may try to fake their responses to personality tests by deliberately increasing their scores on desirable personality traits and decreasing their scores on undesirable traits. However, psychological studies show that even though faking to some extent attenuates the accuracy of personality tests it does not completely neutralize the usefulness of the tests (Rothstein and Goffin 2006, Tett and Christiansen 2007). Moreover, the stylized setting of personality tests allows reducing the opportunities for faking. The forced-choice approach is a common method to limit faking. The effect of perceived desirability on response choices is reduced by presenting statements in pairs, triplets or quartets that assess different traits, but have been equated with respect to the level of perceived desirability. Applicants are instructed to choose the statement that best describes themselves. Because the desirability levels of the choices are equal, applicants are presumed to respond in a more honest manner.

${ }^{17}$ The dependent variable is based on the question 'How many hours do you on average spend on job interviews, tests and so on to screen a successful applicant? We mean the total time an applicant spends in the screening process.' 
${ }^{18}$ The survey first asks employers if the establishment provides variable pay for its employees. For those employers answering in affirmative, there is a second and a third question. The second question asks about the average share of variable pay for managerial and non-managerial employees in relation to their base pay. The third question asks about the shares of individual-based performance pay, group-based performance pay and profit sharing in total variable pay for managerial and non-managerial employees. By multiplying the share of variable pay in relation to base pay with the share of individual-based pay in total variable pay, we obtain our key variables for managerial and non-managerial performance pay. The variables are set equal to zero if the establishment does not provide variable pay to its employees. Accordingly, we construct the control variables for group-based performance pay and profit sharing. 